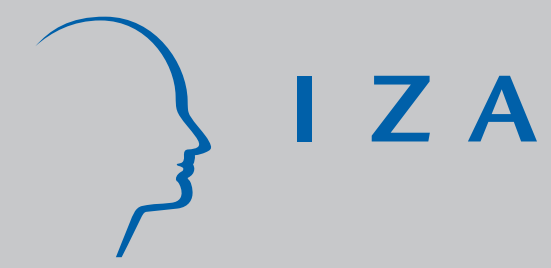

IZA DP No. 676

Agriculture: Transition Buffer or Black Hole?

A Three-State Model of Employment Dynamics

Alexandru Voicu

December 2002 


\title{
Agriculture: Transition Buffer or Black Hole? A Three-State Model of Employment Dynamics
}

\author{
Alexandru Voicu \\ IZA Bonn
}

\author{
Discussion Paper No. 676 \\ Dezember 2002
}

\author{
IZA \\ P.O. Box 7240 \\ D-53072 Bonn \\ Germany \\ Tel.: +49-228-3894-0 \\ Fax: +49-228-3894-210 \\ Email: iza@iza.org
}

This Discussion Paper is issued within the framework of IZA's research area Labor Markets in Transition Countries. Any opinions expressed here are those of the author(s) and not those of the institute. Research disseminated by IZA may include views on policy, but the institute itself takes no institutional policy positions.

The Institute for the Study of Labor (IZA) in Bonn is a local and virtual international research center and a place of communication between science, politics and business. IZA is an independent, nonprofit limited liability company (Gesellschaft mit beschränkter Haftung) supported by the Deutsche Post AG. The center is associated with the University of Bonn and offers a stimulating research environment through its research networks, research support, and visitors and doctoral programs. IZA engages in (i) original and internationally competitive research in all fields of labor economics, (ii) development of policy concepts, and (iii) dissemination of research results and concepts to the interested public. The current research program deals with (1) mobility and flexibility of labor, (2) internationalization of labor markets, (3) welfare state and labor market, (4) labor markets in transition countries, (5) the future of labor, (6) evaluation of labor market policies and projects and (7) general labor economics.

IZA Discussion Papers often represent preliminary work and are circulated to encourage discussion. Citation of such a paper should account for its provisional character. A revised version may be available on the IZA website (www.iza.org) or directly from the author. 
IZA Discussion Paper No. 676

December 2002

\section{ABSTRACT}

\section{Agriculture: Transition Buffer or Black Hole? A Three-State Model of Employment Dynamics}

We analyze the effect of land reform legislation on labor market dynamics in the Romanian economy. We show that the agricultural sector, a source of precarious employment, has become an absorbing state for certain categories of workers who lost their jobs in the nonagricultural sector. A random utility model is used to represent individuals' sequential labor market decisions. The resulting multivariate probit model is estimated using Markov chain Monte Carlo methods.

JEL Classification: C11, C15, C33, C35, J23

Keywords: $\quad$ labor force participation, three-state dynamic model, multivariate probit, Markov chain Monte Carlo, transition economy, land reform

Corresponding author:

Alexandru Voicu

IZA

P.O. Box 7240

D-53072 Bonn

Germany

Tel.: +49 2283894527

Fax: +492283894510

Email: voicu@iza.org 


\section{Introduction}

Land reform has been an important component of the reform packages implemented by transition governments in Central and East European countries. Swinnen (1999), Jackson (1997), Brooks and Meurs (1994) analyze from a political economy perspective the motivations of land reforms, their timing, the choice of alternative land reform procedures, and the effects of the resulting ownership pattern on production efficiency. Land reforms played a crucial role in the process of economic adjustment and had an important effect output, earnings, and labor market dynamics. Yet, to our knowledge, no study has gone beyond the analysis of aggregate economic measures like agricultural employment and output.

This paper studies the effect of land reform legislation on the labor force dynamics in the Romanian economy. It has often been argued that the private agricultural sector is playing an important buffer role with respect to the overall economic restructuring process. Agriculture has provided a source of basic sustenance and employment for those losing jobs in the industrial sector (OECD, 1998). We find that land restitution has created a segmented labor market in rural areas, agriculture being, at best, a source of precarious employment. Agriculture offers low income levels, no returns to education and no opportunities for investment in human capital. The access to social insurance programs is more difficult. A significant proportion of individuals working in the agricultural sector are underemployed and seek jobs in the non-agricultural sector. The analysis of labor force dynamics shows that agriculture has become an absorbing state for certain categories of workers rendered redundant by the restructuring of industrial sector.

The econometric approach is novel in several respects. Like Hyslop (1999), we use a multivariate probit model with a general correlation structure to represent individual employment decisions over time. The main difference is that the state space is three-dimensional. Every time period, individuals choose among three alternatives: employed in the non-agricultural sector, employed in the agricultural sector, and not employed. We allow a general correlation structure both across contemporaneous decisions and across time. The time-variant coefficients of the personal characteristics serve a double purpose. They allow identification of the effects of constant personal characteristics and provide a more accurate description of the out-of-equilibrium process of labor market adjustment. The multivariate probit model is estimated using an extension of the Markov chain Monte Carlo algorithm introduced by Chib and Greenberg (1998). This method allows a high degree of flexibility in model specification and avoids the convergence problems that hamper the maximum likelihood estimation at computational costs comparable to simulated maximum likelihood. The extension accounts for the truncation implicitly introduced by mutually exclusive contemporaneous decisions over the three dimensional state space. The model is estimated using information from the Romanian Labor Force Survey. The three-period panel data set was collected immediately following the implementation of land reform legislation and contains information on individual 
labor force status and personal characteristics.

The remainder of the paper is organized as follows. The next section contains background on the restructuring process and a description of the Romanian land reform. In section 3, we present the data and discuss the characteristics of agricultural employment. The empirical specification and the estimation procedure are presented in section 4 , followed by the results and the concluding remarks.

\section{Background}

Four important components of the restructuring process affected the labor markets in the period to which this study refers:

1. Privatization of the state sector.

2. Restructuring of the remaining state owned enterprises aimed at increasing their productivity.

3. Creation of a new private sector.

4. The emergence of the private agricultural sector following land reform legislation.

Compared to the more advanced transition economies, in Romania, the restructuring process took place at a slow pace in the early 1990s. In spite of the slow pace at which they proceeded, the privatization and restructuring of the state sector, and the emergence of the new private sector had a strong effect on the labor market. In non-agricultural sectors, approximately 1,241,000 jobs (approx. 25 percent of the total) were lost between 1992 and 1996 most of them in large firms in manufacturing sectors, transportation, extraction of crude oil and construction. In the same period only slightly more than 700,000 new jobs were created mainly in small firms. The sectors the fared best in job creation were manufacturing of wood products, trade, utilities, services. This pattern of job creation and destruction indicates the presence an intense process of intersectoral reallocation of labor. Earle (1997) provides a detailed study of labor reallocation among industrial sectors.

The net effect of the process was the reduction of the number of jobs by more than 10 percent between 1992 and 1996. Yet, in the same period both the labor force participation and the unemployment rate remained remarkably stable. The participation rate hovered around 73 percent and registered unemployment, after reaching 11 percent in 1994, fell to about 7 percent in 1996. This somehow puzzling situation is due the sharp increase in employment in agricultural sector.

Land reform legislation started being implemented in January 1990. A comprehensive land law was passed in 1991. In choosing a land reform procedure, the first transition government had to balance historical justice and social equity, and simultaneously build a strong political basis for future elections. The chosen method - a combination of restitution and distribution - fully reflects the trade-off among the above three elements. The land was to be restituted to former owners up to a maximum 10 hectares. Year 1947 was chosen as reference for establishing ownership status. The remaining land was to be distributed among 
poor collective farm workers. Non-land assets, which included most of the capital necessary in production, were privatized using vouchers. Farm employees were compensated for the restitution of land to former owners by receiving 60 percent of non-land assets proportional to the number of years worked in the collective farms. The law also set restrictions on land use and sale and provided for a tax holiday of five years. Swinnen (1999) provides a cross-country comparative analysis of the determinants of land reform procedures from a political economy prospective.

Land reform has created a large class of rural land owners, but private farming has become little more than a subsistence activity. Prior to collectivization, land ownership was fragmented and production was little mechanized. Collectivization allowed land consolidation and introduction of large scale mechanized production. In time, labor has relocated in the industrial sector. Land restitution has recreated the fragmented ownership pattern. The inherited capital lost its efficiency, as it was not appropriate for small scale operations. Furthermore, faulty implementation led to long delays in ownership title distribution. As a result, an undeveloped market has prevented land consolidation. Moreover, land could not be used as collateral to obtain loans for buying new capital.

\section{The dynamics and nature of the private agri- cultural sector}

We use data on individual labor market histories from the Romanian Labor Force Survey, conducted in March 1994 and March 1995. The questionnaire was administered on a representative sample of Romanian households, selected on the basis the population census conducted in January 1992. This survey contains standard labor force participation and unemployment questions about the current status of the respondent. For the purpose of analyzing labor market transitions, it also has two important features. First, the survey contains retrospective questions about the labor market activity of the respondent the year prior to the survey. Thus, we are able to use the 1993 labor market status of the participants in the 1994 survey. The other feature is that nearly all of the respondents in 1994 were re-interviewed in the 1995 survey. With some effort, it is possible to match unambiguously nearly all the cases. Thus, we were able to construct a three-period panel with 22835 observations, including the retrospective information on labor market activity in 1993.

Among the variables in the data set, education deserves special attention. Educational levels as described in the survey differ not only in terms of years of schooling necessary to attain a certain level but also in terms of industry specific, firm specifics, and managerial skills. The level of education is described by the following seven categories: primary school, gymnasium, vocational, high school, foreman, post-high-school training (in presenting the results, I refer to this category as HIPLUS), and university. In the Romanian educational system primary school represents the first four years of education. The gymnasium 
consists of the next four years. After completing the first eight years, a gymnasium graduate may choose either to go to high school or vocational school. The vocational schools are usually run by big industrial firms or co-op associations and provide students with a high level of specific skills. The degree of specificity varies from firm-specific to branch- or sector-specific. Usually, it takes two years to complete vocational school, and at graduation such students are offered a job by the firm that runs the school. Unlike vocational schools, highschool provides students only with general skills. After completing the high school, one may choose either to go to a university or to enter the labor market. There are also two other forms of formal training distinguished in this survey. The posthigh school training can be pursued by the high school graduates and provides students with branch specific skills. Foreman schools provide both technical (branch specific) and managerial training. Firms enroll their employees in the foreman schools and pay all the expenses.

Elsewhere (Voicu, 2001), we show that the private agricultural sector plays no role for urban residents. Therefore, in this paper we will confine our attention to the subsample of rural residents. We define three labor market states: employed in the non-agricultural sector, employed in the private agricultural sector, and not employed. The last category includes both individuals classified as unemployed using ILO definition and non-participants. Table 1 presents the composition of the entire sample by rural/urban residence. On average, rural residents have lower education, a lower percentage of individuals with specific skills. The percentage of women is lower in rural areas and, for both genders, rural residents are older. Most importantly, the private agricultural sector plays no role for rural residents. Only 1-2 percent of urban residents work in private farming as opposed to more than one third of the rural residents.

The sharp increase in the size of the agricultural sector ( 35 percent between 1993 and 1995, table 1) motivates this study. This major inflow had two sources. Individuals that were not employed and, upon receiving land, started reporting normal number of hours in the agricultural sector account for two thirds of the gross inflows. One third is made up by workers who lost their jobs in the industrial sector (tables 2.a - 2.c.). The measure of mobility for transition matrices (Shorrocks, 1978, and Boeri, Flinn, 1999) ranges between 0.25 and 0.36 for year to year transitions. These estimates are larger than similar measures calculated for both transition and developed economies and signal an intense labor reallocation process.

In this paper we argue that the land reform legislation and the restructuring of the industrial sector has created a dual labor market in rural areas. Private farming has become a subsistence activity for workers who lost their jobs in the industrial sector. Many of this sector's characterisitics qualify it as the secondary (informal sector). The private agricultural sector is different from the non-agricultural sector in many respects: the gender, age, and education composition, job status, access to social insurance and unemployment insurance programs. The definition of this sector does not exclude the possibility that a person working in private farming is registered unemployed and receives unemployment benefits. Roughly half of registered unemployed in rural areas work 
in the agricultural sector representing 10 percent of total employment in this sector (tables 3.b, 3.c). An important proportion of the registered unemployed receive unemployment benefits.

The composition of private agricultural sector is in stark contrast with that of the non-agricultural sector. Women account for 53 percent of the agricultural sector, but for only 30 percent of the non-agricultural sector. Individuals working in private farming are on average older. Around 80 percent of them have eight at most eight years of education, while more than 60 percent of those employed in the non-agricultural sector have vocational training or at least highschool education. Ten percent of those working in agriculture are retired, while between 8 and 11 percent declare themselves homemakers. The number of retired and homemakers working in other sectors is negligeable.

The job status is important in two respects. It contains implicit information about the size of economic unit and links the expansion of the agricultural sector to the land reform. The size view of the dual labor market emphasizes the small scale of the economic activity in the informal sector. The overwhelming majority (between 90 and 95 percent) of individuals working in the private agricultural sector are either self-employed or family help. This characteristic provides support for our hypothesis that land reform is the main cause for the deep change of the rural labor market. Self-employed and family help must work the family land and the sharp increase in the number of land owners must be the cause for the expansion of the agricultural sector.

Roughly 10 percent of those working in private farming are looking for a different job as they feel their present occupation is temporary or they need better pay and working conditions. Most of them would prefer a full-time job as a firm's employee but more than half would accept any kind of job. Virtually everybody can start immediately. Everybody would accept a job inferior to their qualifications or would be ready to undergo retraining programs. The only important factor that could determine a searching person to refuse a job is distance from home. This factor appears in three concepts: they would not change residence, they would not take a job too far from home, they would not commute. Moreover, we found no difference between the job seeking behavior of those working in agriculture and that of non-working individuals.

We could not find any significant difference in the proportion of registered unemployed and unemployment benefit recipients across rural/urban residence ${ }^{1}$. Also the proportions of retired people are not significantly different. While this information is important in determining whether the access to pension plans and social insurance programs is more difficult for those employed in the private agriculture, the results based on this particular sample are very likely to hide a potentially important development. In this sample, most retired people have worked either in the collective farms or in the industrial enterprises. Since most of the residents in the main agricultural regions have been members of collective

\footnotetext{
${ }^{1}$ There is however a signifiant difference in the level of income from pensions between agriculture and the non-agricultural sector. Official statistics from 2001 show that the average agricultural pension is one fifth of the average non-agricultural pension. Also the proportion of fully insured is 21 percent among agricultural workers compared to 52 percent for the rest.
} 
farms, it is not surprising that the proportion of retired people is very high. The legislation regarding social insurance has been patched for most of the decade. In 2000 a comprehensive law was passed that was reshaping the public social insurance system. Situation has changed regarding the status of individuals working in agriculture. A very small proportion work in the newly created agricultural associations. Most individuals are either self-employed or family help. According to the law, an employee on a regular contract is automatically insured and contributions are deducted every month from the salary. Other categories of workers, including those we classify as private farmers, are required to register and pay insurance only if they have an annual income equivalent to three average gross wages for the entire economy. This threshold introduces a major difference between agricultural and non-agricultural sector in access to social insurance program. Farming is in most cases a subsistence activity, a large part of the output being produced for self-consumption. If any part of the production is sold it is very likely that the total income will be lower than what is necessary to insure every person working on the family farm. Moreover, making insurance optional, the law introduces a far larger variance in coverage for private farmers than for those working in formal sector. As a result, it is likely that the number of people covered by social insurance will drop making the present agricultural sector far different than the non-agricultural sector. The very same argument holds for the law governing unemployment benefits. The coverage prevailing in this data set is based on work histories prior to 1990. Comprehensive legislation was passed in 2002 and has the same dual structure, as the pension law as far as coverage is concerned. Employees with regular contracts are automatically insured. Other categories, including private farmers, may decide to pay the premium themselves, a minimum contribution being specified. Again, it may be the case that while in principle the access to unemployment benefits does not favor regular employees, in fact, latitude of the choice and non-trivial threshold requirements may create an unequal coverage across sectors. Coverage concerns aside, it is worth mentioning that average pension for individuals who have worked in agriculture is roughly one fifth of that received by those retired from non-agricultural jobs.

The private agricultural sector is very different from the non-agricultural sector in many respects: the gender, age, and education composition, job status, access to social insurance and unemployment insurance programs. The empirical analysis in the remainder of this paper has two goals. First, we go beyond simple statistics in describing the effect of personal characteristics on labor market state occupied by an individual. Second, we determine the role of private farming in the labor market dynamics.

\section{Econometric Model}

Models of multiple individual decisions fall in one of the following three categories: different decisions are made by the same individual at a given time, the same decision is made sequentially, and several different decisions are re- 
peated over time. The main difficulty in estimating such models is accounting for the statistical dependence between different or sequential decisions made by the same person. It is widely accepted that this dependence has three main sources: unobserved heterogeneity, state dependence, and autocorrelated disturbances. For different decisions at a given point in time, the only possible source of correlation is the unobserved heterogeneity - the existence of one or more unobserved individual characteristics relevant to all underlying objective functions. In the economic literature the preferred approach has been the use of random effects. Individual random effects are typically assumed to have a multivariate normal distribution, the correlation coefficients embodying the desired dependence of different decisions. The models are estimated simulated maximum likelihood, as random effects must be integrated out. These models have been used in conjoint analysis in marketing literature ${ }^{2}$.

If one decision is repeatedly observed, all three sources of correlation can play a role. State dependence basically assumes that at any given time, the decision depends in a specified way on the current value of the state variable (for example, in the search model framework, search costs, the value of time spent in alternative activities, or the arrival rate of new wage offers may depend on the labor market state currently occupied). Unobserved heterogeneity works the same way as in the case of different decisions. Finally the correlation matrix can be parametrized to allow the stochastic elements driving the process to be serially correlated ${ }^{3}$.

One interesting feature distinguishes the statistical structure of the lagged dependent variable models and random effects model. Random effects enter the structure of the latent variables determining the discrete choices. As such, it is straightforward to work out their effect on the correlation structure of the latent variables. Lagged dependent variable models are less clear in this respect. Typically, the lagged discrete dependent variable enters linearly the value of the current latent continuous variable. There are several reasons why this is the case. First, one could make the point that some unobserved factors (for example, unemployment benefits) depend solely on the discrete state (employed/unemployed) and this is generally the case in search models. Another purely technical consideration must have certainly played a role in the development of these methods. Absent numerical methods of evaluating multiple integrals, the goal of the estimation is to bring the correlation structure out of the error term. If choices, conditional on observables - including past choice are independent, the integration problem is avoided. This is accomplished by using the lagged discrete dependent variable. The interpretation of the coefficients will in this case be: the effect of a variable on the conditional probability

\footnotetext{
${ }^{2}$ Conlon, Dellaert and van Soest (2000) use simulated maximum likelihood to estimate the model, while Liechty, J., V. Ramaswamy, S. H. Cohen (1999) use a MCMC approach

${ }^{3}$ Hyslop (1999) develops a two-state model of labor force participation with state dependence random effects and serial correlation. The estimation is performed using simualted maximum likelihood.
} 
of occupying a certain state, given the state occupied in the previous period.

If several different decisions are observed over time the number of dependencies increases but there is no substantial difference in the way they can be modeled. The estimation by maximum likelihood becomes increasingly difficult, as higher level multiple integrals have to be evaluated within each step of the maximization routine. There are only a few examples of studies in this category. They all use random effects to model the dependence across sequential decisions. The main drawback of this approach is that it imposes a constant correlation between sequential decisions. When multivariate logit model is used to model contemporary decisions, it imposes the additional restriction that the random utilities corresponding to each choice are independent.

The multivariate probit model we use in this paper allows a general correlation structure both across choices and over time. In this respect it is the most general framework we are aware of. As we are not estimating a structural model, it is less important to break down dependence into state dependence and unobserved heterogeneity. However, we are able to estimate the effect of past status on present decision using simple conditional probabilities. Again, our approach is more general than the usual method of using lagged dependent variable in the present decision. It does not suppress the dependence beyond the immediate past status and allows for a more general dependence than the simple linear relationship between the past status and the expected value of the current latent dependent variable.

To study the role of private farming in labor market dynamics we employ a three-state labor force participation model where we distinguish between employment in agriculture and employment in the non-agricultural sector. We use a simple random utility model to represent individual labor market experiences in this three-dimensional state space. In this setting, every time period, individuals choose among three alternative states: employed in the non-agricultural sector, employed in the agricultural sector, and not employed. Each state is associate with a latent variable which can be thought of as the utility of being in the respective state. Every time period, individuals draw realizations of the three latent variables from a known joint distribution. Upon comparing the values of the latent variables, individuals choose the state for the current period.

Let the three latent variables be $Z_{i t}^{n a g}, Z_{i t}^{a g}$, and $Z_{i t}^{n w}$, corresponding to the three states - employed in the non-agricultural sector, employed in the agricultural sector, and not employed, respectively.

$$
\begin{aligned}
Z_{i t}^{n a g} & =X_{i} \beta_{t}^{n a g}+u_{i t}^{n a g} \\
Z_{i t}^{a g} & =X_{i} \beta_{t}^{a g}+u_{i t}^{a g} \\
Z_{i t}^{n w} & =X_{i} \beta_{t}^{n w}+u_{i t}^{n w}
\end{aligned}
$$

$u_{i t}^{n a g}, u_{i t}^{a g}$, and $u_{i t}^{n w}$ have a joint multivariate normal distribution. The dimension of the distribution is $3 T$. Let $u_{i t}=\left[u_{i t}^{n a g}\left|u_{i t}^{a g}\right| u_{i t}^{n w}\right] . E\left[u_{i t}\right]=0, u_{i t}$ are independent over $i$ 's and it has a correlation structure over $t$ given by a general 
$3 T \times 3 T$ correlation matrix. The number of free elements in the correlation matrix is

$3 T(3 T-1) / 2$

The state choice is represented by a set of binary variables defined in the following way:

$$
\begin{aligned}
y_{i t}^{n a g} & =1 \text { if } Z_{i t}^{n a g}>Z_{i t}^{a g} \text { and } Z_{i t}^{n a g}>Z_{i t}^{n w} \\
y_{i t}^{a g} & =1 \text { if } Z_{i t}^{a g}>Z_{i t}^{n a g} \text { and } Z_{i t}^{a g}>Z_{i t}^{n w} \\
y_{i t}^{n w} & =1 \text { if } Z_{i t}^{n w}>Z_{i t}^{n a g} \text { and } Z_{i t}^{n w}>Z_{i t}^{a g}
\end{aligned}
$$

Without loss of generality, we can redefine the binary variables.

$$
\begin{aligned}
y_{i t}^{n a g} & =1 \text { if } Z_{i t}^{n a g}>0, Z_{i t}^{a g}<0, \text { and } Z_{i t}^{n w}<0 \\
y_{i t}^{a g} & =1 \text { if } Z_{i t}^{a g}>0, Z_{i t}^{n a g}<0, \text { and } Z_{i t}^{n w}<0 \\
y_{i t}^{n w} & =1 \text { if } Z_{i t}^{n w}>0, Z_{i t}^{n a g}<0 \text {, and } Z_{i t}^{a g}<0
\end{aligned}
$$

This structure closely resembles that of a multivariate probit model. The difference consists of additional truncation imposed on contemporary latent variables by the fact that only one choice can be made at any given time. To estimate this model, we use an extension of the Markov chain Monte Carlo algorithm introduced by Chib and Greenberg (1998). The extension deals specifically with this additional truncation.

Statistical and econometric models typically contain a large number of parameters, and in Bayesian inference we need to obtain the posterior probability density or posterior summary statistics (such as the mean and standard deviation) of a parameter of interest by integrating out nuisance parameters. A closed form solution to integration exists for the linear regression model with the Gaussian error term. In many current applications, however, we have to work with models where closed form solutions do not exist and we need to resort to numerical integration procedures.

Let $y_{i t}=\left[y_{i t}^{n a g}\left|y_{i t}^{a g}\right| y_{i t}^{n w}\right], y_{i}=\left[y_{i 1}\left|y_{i 2}\right| \ldots \mid y_{i T}\right], y=\left[y_{1}\left|y_{2}\right| \ldots \mid y_{n}\right]$,

$$
Z_{i t}=\left[Z_{i t}^{n a g}\left|Z_{i t}^{a g}\right| Z_{i t}^{n w}\right], Z_{i}=\left[Z_{i 1}\left|Z_{i 2}\right| \ldots \mid Z_{i T}\right], Z=\left[Z_{1}\left|Z_{2}\right| \ldots \mid Z_{n}\right] .
$$

The major difference between our model and that of Chib and Greenberg (1998) is that the vector $y$ is restricted to a set of all possible combinations of values. Any time period, an individual can be in one and only one state. This means that, any time period, only three combinations of values are feasible out of a total of eight. This induces an additional truncation for the joint distribution of $Z_{i}$. Not only is the distribution of each component restricted by the value of the corresponding discrete dependent variable, but the joint distribution is further truncated to the space of feasible combinations for the components of $y_{i}$. This does not affect the estimation but any predictions made on the basis of the results have to be adjusted to account for this additional truncation.

Define $B_{i t}^{n a g}=(0, \infty) \times(-\infty, 0] \times(-\infty, 0], B_{i t}^{a g}=(-\infty, 0] \times(0, \infty) \times$ $(-\infty, 0], B_{i t}^{n w}=(-\infty, 0] \times(-\infty, 0] \times(0, \infty)$. Every time period, the set of 
possible values form $Z_{i t}$ is given by $B_{i t}=B_{i t}^{n a g} \cup B_{i t}^{a g} \cup B_{i t}^{n w}$. For individual $i$, the set of all feasible values of $Z_{i}$ is $B_{i}=B_{i 1} \times B_{i 2} \times \ldots \times B_{i T}$

Using Bayes formula, the joint posterior distribution of the parameters conditional on data is

$$
\pi(\beta, \sigma \mid y) \propto \pi(\beta, \sigma) \operatorname{pr}(y \mid \beta, \Sigma) \beta \in R^{k}, \sigma \in C
$$

where $\pi(\beta, \sigma)$ is the prior distribution of $\beta$ and $\sigma$, and $\operatorname{pr}(y \mid \beta, \Sigma)=\prod_{i} \operatorname{pr}\left(y_{i} \mid \beta, \Sigma\right)$ is the likelihood function. $\mathrm{C}$ is a convex solid body in the hypercube $[-1,1]$ (Rousseeuw and Molenberghs, 1994). The shape of $\mathrm{C}$ is given by the following two conditions:

1. Each correlation coefficient lies in the interval $[-1,1]$.

2. The correlation matrix $\Sigma$ is positive definite. Since $\Sigma$ is symmetric, this condition reduces to $\operatorname{det}(\Sigma)>0$.

The method proposed by Chib and Greenberg (1998) uses the same approach as data augmentation algorithm of Tanner and Wong (1987). Instead of using the posterior distribution in this form, we use the joint posterior of both parameters and latent variables, $\pi\left(\beta, \sigma, Z_{1}, \ldots, Z_{n} \mid y\right)$.

$$
\pi(\beta, \sigma, Z \mid y) \propto \pi(\beta, \sigma) f(Z \mid \beta, \Sigma) \operatorname{pr}(y \mid Z, \beta, \sigma)
$$

Conditional on $Z_{i}, \operatorname{pr}\left(y_{i} \mid Z_{i}, \beta, \sigma\right)=I\left(Z_{i} \in B_{i}\right)$. The posterior distribution becomes

$$
\pi(\beta, \sigma, Z \mid y) \propto \pi(\beta, \sigma) \prod_{i} f\left(Z_{i} \mid \beta, \Sigma\right) I\left(Z_{i} \in B_{i}\right)
$$

where

$$
f\left(Z_{i} \mid \beta, \Sigma\right) \propto|\Sigma|^{-\frac{1}{2}} \exp \left\{-\frac{1}{2}\left(Z_{i}-X_{i} \beta\right)^{\prime} \Sigma^{-1}\left(Z_{i}-X_{i} \beta\right)\right\} I(\sigma \in C)
$$

Regarding the latent variable as a parameter, we sample from the conditional distributions:

- Conditional distribution of $Z_{i}$

$\left[Z_{i} \mid y_{i}, \beta, \Sigma\right] \propto \phi_{T}\left(Z_{i} \mid X_{i} \beta, \Sigma\right) \prod_{i}\left\{I\left(z_{i t}>0\right) I\left(y_{i t}=1\right)+I\left(z_{i t} \leq 0\right) I\left(y_{i t}=0\right)\right\}$

To draw from a truncated normal distribution, I used the method proposed by Geweke (1991), which consists of running a Gibbs sub-chain with T steps within the main Gibbs sampler cycle. 
- Conditional Distribution of $\beta$

We assume prior independence between $\beta$ and $\sigma$. The prior distribution of $\beta$ is a $\mathrm{k}$-variate normal distribution $\pi(\beta)=\phi_{k}\left(\beta \mid \beta_{0}, B_{0}^{-1}\right)$. Conditional distribution is

$$
[\beta \mid Z, \Sigma] \sim N_{k}\left(\beta \mid \hat{\beta}, B^{-1}\right)
$$

where $\hat{\beta}=B^{-1}\left(B_{0} \beta_{0}+\sum_{i=1}^{n} X_{i}^{\prime} \Sigma^{-1} Z_{i}\right)$ and $B=B_{0}+\sum_{i=1}^{n} X_{i}^{\prime} \Sigma^{-1} X_{i}$

- Conditional Distribution of $\sigma$

$$
\begin{aligned}
\pi(\sigma \mid Z, \beta) & \propto \pi(\sigma) f(Z \mid \beta, \Sigma) \\
f(Z \mid \beta, \Sigma) & \propto|\Sigma|^{-\frac{n}{2}} \exp \left\{-\frac{1}{2} \operatorname{tr}\left(Z^{*}-\Delta\right)^{\prime} \Sigma^{-1}\left(Z^{*}-\Delta\right)\right\} I(\sigma \in C)
\end{aligned}
$$

where $Z^{*}=\left(Z_{1}, \ldots, Z_{n}\right)$ and $\Delta=\left(X_{1} \beta, \ldots, X_{n} \beta\right)$.

Prior distribution of $\sigma$ is a normal distribution truncated at $C$.

$$
\pi(\sigma) \propto \phi_{p}\left(\sigma \mid \sigma_{0}, G_{0}^{-1}\right), \sigma \in C
$$

where $p$ is the number of free parameters in the correlation matrix.

To draw from this distribution I use a MH step within the Gibbs sampler.

Convergence of the chain is assessed using the method proposed by Gelman and Rubin (1992) with the modified correction factor proposed by Brooks and Gelman (1998). One preliminary run of 15000 iterations, with OLS coefficients as starting values, was used to construct starting values for three independent chains. The starting values were extreme values chosen form the posterior distribution of the coefficients. The three independent chains, each with 15000 iterations and the initial run were used to compute the scale reduction factor. We also evaluated the convergence criterion proposed by Geweke(1992) based on a single chain, which uses spectral density estimates of the series. Both criteria indicated that the chain converges fast to the stationary distribution.

We follow Chib and Greenberg (1998) in setting the parameters of the algorithm. The prior distribution of $\beta$ is multivariate normal with a mean vector of 0 and a variance matrix of 100 times the identity matrix. The prior distribution of the elements of the correlation matrix is multivariate normal with a mean vector of 0 and a variance matrix equal to 10 times the identity matrix. The proposal density used to generate candidate values in the MH step is $q\left(\phi \mid \sigma_{i}^{k}\right)=s * g\left(\phi-\sigma_{i}^{k}\right)$ where $g$ is the standard normal distribution and $s$ is the step size. We use a step size $s=1 / \sqrt{N}$. 


\section{Results}

Our broad goal is to analyze the effect of land reform legislation on labor market dynamics. In the previous sections we provide evidence that private farming is in many respects a different type of employment. The results of the empirical analysis allow us to provide a sharper picture of the role of agriculture in labor market transformations. We provide evidence that private farming and the nonagricultural sector are very different in nature and analyze the determinants of employment in the agricultural sector. The dynamics of the labor reallocation process is our main interest. The flows between the non-agricultural sector and private farming are the most important but the three state model we employ allows us a deeper analysis of the labor reallocation process. We analyze the composition and the intensity of both the outflows from the industrial sector and the inflows into agriculture. Finally, we determine if agriculture is a transition or an absorbing state in the labor reallocation process.

Our empirical strategy entails several distinct elements. We start by estimating the model slope and correlation coefficients. The results of the Gibbs sampler are dependent draws from the joint distribution of the parameters of the model. For each parameter, we report the moments of the posterior distribution, the numerical standard error of the estimated mean, which accounts for dependence of successive draws, and evaluate the convergence of the MCMC algorithm. We briefly discuss some implications of the results.

Next, we calculate the probabilities of three types of events:

1. Probability of being in a given state in each of the three years of the panel.

2. Probability of transition among states.

3. Conditional probability of transition among states.

The probabilities are calculated for 14 categories of individuals who differ with respect to their gender and education. For each category, we estimate the above probabilities at all ages between 16 and 65. In a three-period twostate model, there are eight possible histories. The probability of a complete history is the cumulative distribution function (CDF) of a trivariate normal distribution. To calculate the normal CDFs, we use the GHK smooth recursive simulator (Geweke, 1989; Hajivassiliou, 1990; and Keane, 1994. Greene, 1997). The probabilities corresponding to the eight possible histories are evaluated at the posterior means ${ }^{4}$. The results are used to calculate the employment probabilities, the transition probabilities, and the conditional probabilities. Most of the discussion in this section is based on the analysis of these probabilities. To summarize the large amount of information, and simplify the presentation, instead of tabulating the probability values, we graph the age-probability profiles for each type of event.

\footnotetext{
${ }^{4}$ We have also used an alternative approach for computing the probabilities: for all categories we computed the probabilities at each Gibbs sampler step, checked the convergence of the quantities using Geweke's single-chain convergence measure (CD). The results were very similar with much higher computational cost.
} 
We estimate nine sets of coefficients: one for every labor market state-year. Tables 4.a-4.c, for employed in the non-agricultural sector, 5.a-5.c. for employed in the agricultural sector, and 6.a.-6.c. for not employed, report the posterior means, the posterior standard deviation (PSTD), and the numerical standard errors (NSE) for the $\beta$ s and the scale reduction factors $(\mathrm{R})$. The values of $\mathrm{R}$ very close to 1 indicate convergence. The interpretation of the $\beta s$ is the same as that in a linear regression model with dependent variable $Z_{i t}$.

The effect of personal characteristics are similar for the agricultural sector and non-employment and very different from employment in the non-agricultural sector. This an indication that private farming is a different type of employment. Men are more likely to work in the non-agricultural sector and less likely to work in private farming or be not-employed. The age profiles are concave for the non-agricultural sector and convex for agriculture and non-employment. In general a higher level of education or a higher level of specific skills (foreman, vocational) improves the likelihood of working in the non-agricultural sector and reduces the likelihood of working in agriculture and non-employment. The effect of specific human capital has dramatically changed over time: the absolute values of the coefficients have dropped dramatically for all three labor market states. Individuals with these types of education have become relatively more likely to be private farmers or not employed and less likely to work in the industrial sector.

High correlation coefficients of the three error terms (tables 7.a - 7.c.) validate the choice of a multivariate probit model for this application. Imposing restrictions on the form of the correlation matrix (for example, estimating the model as an independent probit model), would have led to incorrect inferences. They also indicate a strong persistence in individual labor force histories. The sector displaying the least persistence is non-employment. The crosscorrelations are negative both for contemporaneous decisions and aver time. The strongest negative correlations are between the non agricultural and agricultural sectors reinforcing the finding that the two types of employment are very different. The correlation declining with time interval indicates the presence of an autocorrelated component of the stochastic process governing employment decisions, but different one-period correlation hints to a non-stationary process. The non-stationarity does not come as a surprise given the fact that labor reallocation at the beginning of the transition period can hardly be regarded as an equilibrium process.

The age-probability profiles for the three labor market states (figures 1, 2, and 3 ) provide a rich picture of the Romanian rural labor market. Rural residents start their life-time profiles either in non-employment or working in the agricultural sector. The probability of working in the agricultural sector is higher for low educated individuals. If they acquire higher education of specific training they have a higher chance of finding a job outside agriculture. Regardless of education, women are more likely to stay at home. Women with a low level of education have virtually no chance of finding a non-agricultural job and eventually form the bulk of the agricultural employment. Most men spend some of their life - more likely and for a longer period of time for those with higher 
education - in a non-agricultural job. Most of them - the proportion is higher for those with lower education - retire into private farming. The significant changes in the profiles over time are consistent with the increase in the size of the private agricultural sector.

The age-probability profiles are concave for the non-agricultural sector (figure 1). Individuals with higher education and specific human capital have higher profiles. They also maintain high employment probabilities for longer periods of time. There is a striking difference between men and women. For all ages, women have a much lower probability of holding a job in the non-agricultural sector. The difference is higher for lower levels of education. For all levels of education the age probability profiles have shifted down over time. The decrease was more dramatic for women, specially for those with specific human capital.

Women are more likely to work in agriculture. For both genders and levels of education, the probability of working in agriculture has increased over time. The change was more significant for women, specially for those with specific skills. Higher education and specific human capital reduce the probability of working in agriculture. The shape of the profiles differs significantly across education and gender. Both men and women start their life time profiles with relatively high probabilities of working in agriculture. This probability is higher for individuals with lower education but it is comparable for the two genders. As individuals become older they are more likely to find jobs in the industrial sector, therefore, the profiles dip during the prime labor market age. This is true for men in all educational categories, but education plays a significant role:the profiles are deeper for higher educated men. The same is true for women, with one notable exception. Lower educated women show a persistent increase in the probability of working in agriculture throughout their life-time. The maximum probability is attained by older individuals. The maxima are higher for low education levels. Even though men have experienced lower probabilities of working in agriculture throughout their life-time, close to the retirement age they bounce back to levels comparable to those of women.

Individuals with low education do not retire (figure 3), they continue to work in agriculture. Women are less likely to work, the difference between profiles being larger for individuals with specific human capital.

To study labor market dynamics, we use two instruments. The transition probability (for example, $\left.P\left(N A G_{t}, A G_{t-1}\right), P\left(A G_{t}, N A G_{t-1}\right)\right)$ gives an absolute measure of the flows among labor force states. The conditional probability (for example, $P\left(N A G_{t} \mid A G_{t-1}\right), P\left(A G_{t} \mid N A G_{t-1}\right)$ ) describes the speed of the transition. A larger flow - more individuals moving between states - can be caused by either a larger number of individuals in the origin state or a higher probability (speed) of moving. Conditional probabilities are also good indicators of individuals' ability to adapt to labor market transformations.

Very few individuals with primary education work in the non-agricultural sector and most of them are men. As a result, the probability of moving to agriculture is low - relatively higher for men - and the shape of the age probability profile is heavily determined by the number of people working in agriculture (figure 4). As the level of education increases, older individuals and women 
account for a larger part of the flows. Conditional probabilities strengthen this finding (figure 5). For all levels of education and ages women are more likely to move from the industrial sector to agriculture. Higher education and specific skills reduce individuals' vulnerability to this transition. Older individuals are the most likely to move to agriculture if they lose their jobs.

Non-employment is playing a less important role than agriculture as destination of flows from the industrial sector. Transition probabilities are very low for most educational categories (figure 6). Again women are more likely to lose their jobs in the industrial sector and move into non-employment. A comparison of conditional probabilities for the transitions from the non-agricultural sector to agriculture (figure 5) and from the non-agricultural sector to non-employment (figure 7) reveal that young individuals are more likely to become non-employed if they lose their jobs, while older individuals will predominantly start working in farming.

The inflows into agriculture driving the dramatic increase in the size of this sector are coming from both industrial sector and non-employment (figures 4 and 8 ). Very young and very old movers into agriculture come from non-employment. For most levels of education, prime age individuals are more likely to hold jobs in the industrial sector and therefore this sector is the primary source. For individuals with high levels of education, there is no significant distinction. For them agriculture does not play an important role. Conditional on being nonemployed women are more likely to become employed in the agricultural sector, for all ages and levels of education (figure 9).

Agriculture has become an absorbing state for low educated workers, and for older workers with specific skills. At the same time, it represents a subsistence buffer for prime age individuals with specific skills or high school education who lose their jobs during restructuring on the industrial sector. The difference between the transition probabilities are positive for men and women, for all ages and levels of education. They are higher for women and older individuals (figure 10). These differences capture very well the net flows between the two sectors. Conditional probabilities describe a person's ability to return to the industrial sector after losing his or her job and spending time in private farming. For individuals with low levels of education (primary and gymnasium) agriculture is an absorbing state regardless of gender and age. For individuals with high levels of education (HIPLUS and university) agriculture plays the role of a buffer state (figure 11). The chance of it becoming a long term occupation is small. The story is different for individuals with specific skills. Older individuals with specific skills and those with highschool education are likely to be absorbed into agriculture if they lose their jobs, whereas prime age individuals will find it easy to return to better quality industrial jobs. For all levels of education and ages, women are more likely to find themselves stuck in agriculture after losing their jobs in the non-agricultural sector. 


\section{Conclusion}

This paper studies the effect of land reform legislation on the labor force dynamics in the Romanian economy. Data on individual labor market histories from the Romanian Labor Force Survey, collected shortly after the land reform legislation was passed, provide an unique empirical framework. We use a random utility model to represent individuals' sequential labor market decisions. Every time period, individuals choose among three states: employed in the nonagricultural sector, employed in agriculture, and not employed. The resulting multivariate probit model is estimated using Markov chain Monte Carlo methods. Our approach is novel in several respects. We use a three-dimensional state space and allow for a general correlation structure both across contemporary decision and across sequential decisions.

We argue that land reform has created a dual labor market in rural areas. We document the differences between agriculture and non-agricultural sector in terms of definition, composition, status/size of establishment, underemployed/job search behavior and access to social insurance. The empirical analysis shows that employment in the non-agricultural sector and private farming are very different with respect to the effect personal characteristics on the probabilities. The correlation coefficients indicate a strong persistence in individual labor market histories. The strong negative correlation between the non-agricultural and agricultural sectors are consistent with unobserved characteristics having opposite effects on the corresponding random utilities. Age, gender, and education are strong determinants of the labor market history. High level of education and specific skills improve the probability of working in the non-agricultural sector. There has been, however, a dramatic change in the effect of specific skills, individuals in this category becoming increasingly likely to move to agriculture. Gender has a strong and sweeping effect. For all ages and levels of education, women are less likely to find a job in the industrial sector. If they have a job, they are more likely to lose it and move to the agricultural sector. They are also more likely to move from non-employment to employment.

From a dynamic point of view, agriculture plays a dual role. For prime age individuals with specific skills and higher level of education agriculture represents a buffer state that provides a temporary source of income. For low educated individuals and for older individuals in most educational categories, agriculture is an absorbing state. The chances of returning to work in the nonagricultural sector are very low. Agriculture plays no role for workers with high level of education.

The findings are important from a policy point of view. Agriculture has played an important role in taking people off the unemployment rolls and providing basic subsistence to a large proportion of rural residents. However, the land ownership patterns and the overall low productivity make private farming, at best, a source of precarious employment with low levels of income and difficult access to social insurance programs. Far from being a temporary state, agriculture has become an absorbing state for certain categories of workers hiding long-term unemployed and discouraged workers. Hence, active labor market 
policies need to be targeted towards bringing rural labor force back into the formal sector. Policies designed to improve access to higher education for rural residents are necessary to improve individuals' labor market performance. 


\section{References}

Boeri, Tito and Flinn, Christopher J., "Returns to Mobility in the Transition to a Market Economy." Journal of Comparative Economics, 27, 4-32, 1999.

Brooks, Karen and Meurs Mieke, "Romanian Land Reform: 1991-1993." Comparative Economic Studies, 36, 17-32, 1994.

Brooks, Stephen P. and Gelman, Andrew, "General Methods for Monitoring Convergence of Iterative Simulations." Journal of Computational and Graphical Statistics, 7, 434-455, 1998.

Chib, Siddhartha, and Greenberg, Edward, "Analysis of Multivariate Probit Models." Biometrika, 85, 347-361,1998.

Conlon, Bernard, Dellaert, Benedict G. C., and van Soest, Arthur, "Combining and Comparing Consumers' Stated Preference Ratings and Choice Responses." Mimeo, Center for Economic Research, Tilburg, 2000

Earle, John S., "Industrial Decline and Labor Reallocation in Romania," SITE working paper, 1997.

Gelman, Andrew and Rubin, Donald F., "Inference form Iterative Simulations Using Multiple Sequences" (with discussion). Statistical Science, 7, 457511, 1992.

Geweke, John, "Bayesian Inference in Econometric Models Using Monte Carlo Integration." Econometrica, 57,1317-1340,1989.

Geweke, John, "Efficient Simulation from the Multivariate Normal and StudentT Distributions Subject to Linear Constaraints." In E. Keramidas and S. Kaufman, Eds., Computing Science and Statistics: Proceedings of the 23rd Symposium on the Interface, 571-578. Fairfax Station, VA: Interface Foundation of North American, 1991.

Geweke, John, "Evaluating the Accuracy of Sampling-Based Approaches to the Calculation of Posterior Moments." In J.M. Bernardo, J.O. Berger, A.P. David, and A.F.M. Smith Eds., Bayesian Statistics, Vol. 4, 169-193, 1992.

Greene, William H. Econometric Analyisis. Prentice Hall, 1997.

Hajivassiliou, Vassilis A., "Smooth Simulation Estimation of Panel Data LDV Models," Department of Economics, Yale University, 1990.

Hyslop, Dean, "State Dependence, Serial Correlation and Heterogeneity in Intertemporal Labor Force Participation of Married Women." Econometrica, 67, 1255-1294, 1999. 
Jackson, Marvin, "Political Economy of Agricultural Reform in Romania." In Swinnen, J. Ed., Political Economy of Agrarian Reform in Central and Eastern Europe, Avebury: Aldershot, 1997.

Keane, Michael P., "A Computationally Practical Simulation Estimator for Panel Data." Econometrica, 62, 95-116, 1994.

Liechty, J., V. Ramaswamy, S. H. Cohen, 1999, "Menu-Based Conjoint Ananlysis for Mass Customization: An Application to a Web-Based Information Service," mimeo, Pennsylvania State University.

Organisation for Economic Co-operation and Development, OECD Economic Surveys, 1998: Romania, 1998.

Rousseeuw, P. and G. Molenberghs, "The Shape of the Correlation Matrix." American Statistician, 48, 276-279, 1994.

Shorrocks, Anthony F., "The Measurement of Mobility." Econometrica 46, 1013-1024, 1978.

Swinnen, Johan F. M., "The Political Economy of Land Reform Choices in Central and Eastern Europe." Economics of Transition, 7, 637-664, 1999.

Tanner, Martin A., and Wong, Wing Hung, "The Calculation of Posterior Distributions by Data Augmentation." Journal of the American Statistical Association, 82, 528-549,1987.

Voicu, Alexandru, "Labor Force Participation Dynamics in the Romanian Labor Market. A Bayesian Markov Chain Monte Carlo Approach," Ph.D. Thesis, Rutgers University, 2001. 
Table 1. Sample composition

\begin{tabular}{||l|ccc||c|c|c||}
\hline \hline & \multicolumn{3}{|c||}{ Urban residents } & \multicolumn{3}{c||}{ Rural residents } \\
\hline \hline TOTAL & & 12594 & & 10241 & \\
Gender & Female & Male & Total & Female & Male & Total \\
& 6340 & 6254 & 12594 & 4661 & 5580 & 10241 \\
Education & Female & Male & Total & Female & Male & Total \\
Primary & 394 & 295 & 689 & 1236 & 1049 & 2285 \\
Gymnasium & 1739 & 1184 & 2923 & 1953 & 1881 & 3834 \\
Vocational & 991 & 1895 & 2886 & 455 & 1588 & 2043 \\
High-school & 2261 & 1443 & 3659 & 862 & 780 & 1642 \\
Foreman & 46 & 419 & 465 & 9 & 113 & 122 \\
HIPLUS & 364 & 223 & 587 & 74 & 53 & 127 \\
University & 590 & 795 & 1385 & 72 & 116 & 188 \\
Age & Female & Male & Total & Female & Male & Total \\
Mean & 35.42 & 37.07 & 37.08 & 37.51 & 38.60 & 38.11 \\
L.M. State & Female & Male & Total & Female & Male & Total \\
NAG93 & 3869 & 4265 & 8134 & 1201 & 2733 & 3934 \\
AG93 & 60 & 69 & 129 & 1781 & 1467 & 3248 \\
NE93 & 2411 & 1920 & 4331 & 1679 & 1380 & 3059 \\
NAG94 & 3691 & 4276 & 7967 & 1092 & 2699 & 3791 \\
AG94 & 92 & 106 & 198 & 2353 & 1783 & 3870 \\
NE94 & 2557 & 1872 & 4429 & 1243 & 1098 & 2580 \\
NAG95 & 3695 & 4324 & 8019 & 1065 & 2618 & 3683 \\
AG95 & 122 & 130 & 252 & 2353 & 2019 & 4372 \\
NE95 & 2523 & 1800 & 4323 & 1243 & 943 & 2186 \\
\hline \hline
\end{tabular}


Transition matrices

Table 2a. Transition matrix 1993-1994

\begin{tabular}{|c|l|l|l|l|l|}
\cline { 3 - 6 } \multicolumn{2}{c|}{} & \multicolumn{4}{|c|}{1994} \\
\cline { 3 - 6 } 1993 & NAG & AG & NE & Total \\
\cline { 2 - 6 } & AG & 3389 & 270 & 275 & 3934 \\
\cline { 2 - 6 } & NE & 315 & 57921 & 140 & 3248 \\
\cline { 2 - 6 } & Total & 3791 & 3870 & 2580 & 10241 \\
\hline
\end{tabular}

Table 2b. Transition matrix 1994-1995

\begin{tabular}{|l|l|l|l|l|l|}
\cline { 3 - 6 } \multicolumn{2}{c|}{} & \multicolumn{4}{c|}{1995} \\
\cline { 3 - 6 } & NAG & AG & NE & Total \\
\hline \multirow{3}{*}{1994} & NAG & 3112 & 415 & 264 & 3791 \\
\cline { 2 - 6 } & AG & 309 & 3163 & 398 & 3870 \\
\cline { 2 - 6 } & NE & 262 & 794 & 1524 & 2580 \\
\cline { 2 - 6 } & Total & 3683 & 4372 & 2186 & 10241 \\
\hline
\end{tabular}

Table 2c. Transition matrix 1993-1995

\begin{tabular}{|l|l|l|l|l|l|}
\cline { 3 - 6 } \multicolumn{2}{c|}{} & \multicolumn{4}{|c|}{1995} \\
\cline { 3 - 6 } 1993 & NAG & AG & NE & Total \\
\cline { 2 - 6 } & NAG & 2997 & 569 & 368 & 3934 \\
\cline { 2 - 6 } & AG & 238 & 2679 & 331 & 3248 \\
\cline { 2 - 6 } & NE & 448 & 1124 & 1487 & 3059 \\
\cline { 2 - 6 } & Total & 3683 & 4372 & 2186 & 10241 \\
\hline
\end{tabular}


Table 2d. Complete labor force histories

\begin{tabular}{||l|l|l|l|l||}
\hline \hline & \multicolumn{3}{|c|}{ Status } & Observations \\
\hline 1 & NAG & NAG & NAG & 2894 \\
\hline 2 & NAG & NAG & AG & 301 \\
\hline 3 & NAG & NAG & NE & 194 \\
\hline 4 & NAG & AG & NAG & 44 \\
\hline 5 & NAG & AG & AG & 201 \\
\hline 6 & NAG & AG & NE & 25 \\
\hline 7 & NAG & NE & NAG & 59 \\
\hline 8 & NAG & NE & AG & 67 \\
\hline 9 & NAG & NE & NE & 149 \\
\hline 10 & AG & NAG & NAG & 41 \\
\hline 11 & AG & NAG & AG & 39 \\
\hline 12 & AG & NAG & NE & 7 \\
\hline 13 & AG & AG & NAG & 188 \\
\hline 14 & AG & AG & AG & 2556 \\
\hline 15 & AG & AG & NE & 277 \\
\hline 16 & AG & NE & NAG & 9 \\
\hline 17 & AG & NE & AG & 84 \\
\hline 18 & AG & NE & NE & 47 \\
\hline 19 & NE & NAG & NAG & 177 \\
\hline 20 & NE & NAG & AG & 75 \\
\hline 21 & NE & NAG & NE & 63 \\
\hline 22 & NE & AG & NAG & 77 \\
\hline 23 & NE & AG & AG & 406 \\
\hline 24 & NE & AG & NE & 96 \\
\hline 25 & NE & NE & NAG & 194 \\
\hline 26 & NE & NE & AG & 643 \\
\hline 27 & NE & NE & NE & 1328 \\
\hline \hline & & & & \\
\hline
\end{tabular}


Table 3.a

\begin{tabular}{||l|l|l|l|l||}
\hline \hline & NAG93 & AG93 & NE93 & Total \\
\hline Total & 3934 & 3248 & 3059 & 10241 \\
Male & 2733 & 1467 & 1380 & 5580 \\
Female & 1201 & 1781 & 1679 & 4661 \\
& & & & \\
Mean Age & 37.81 & 43.30 & 32.97 & 38.11 \\
& & & & \\
Education & & & & \\
Primary & 326 & 1270 & 689 & 2285 \\
Gymnasium & 1064 & 1480 & 1290 & 3834 \\
Vocational & 1301 & 283 & 459 & 2043 \\
Foreman & 88 & 11 & 23 & 122 \\
Highschool & 885 & 195 & 562 & 1642 \\
HIPLUS & 103 & 5 & 19 & 127 \\
University & 167 & 4 & 17 & 188 \\
& & & & \\
Self-empl. & 82 & 1835 & & \\
Family help & 12 & 1107 & & \\
\hline \hline
\end{tabular}


Table 3.b

\begin{tabular}{||l|l|l|l|l||}
\hline \hline & NAG94 & AG94 & NE94 & Total \\
\hline Total & 3791 & 3870 & 2580 & 10241 \\
Male & 2699 & 1783 & 1098 & 5580 \\
Female & 1092 & 2087 & 1482 & 4661 \\
Mean Age & 36.35 & 42.20 & 34.54 & 38.11 \\
& & & & \\
Education & & & & \\
Primary & 289 & 1391 & 605 & 2285 \\
Gymnasium & 980 & 1718 & 1136 & 3834 \\
Vocational & 1225 & 446 & 372 & 2043 \\
Foreman & 83 & 17 & 22 & 122 \\
Highschool & 937 & 284 & 421 & 1642 \\
HIPLUS & 108 & 8 & 11 & 127 \\
University & 169 & 6 & 13 & 188 \\
& & & & \\
Self-empl. & 104 & 1792 & & \\
Family help & 15 & 1802 & & \\
Regist. UE & 37 & 426 & 407 & \\
UE benefits & 27 & 385 & 365 & \\
Retired & 9 & 381 & 440 & \\
Homemaker & 6 & 462 & 671 & \\
Second job & 904 & 131 & & \\
Search & 59 & 326 & & \\
& & & & \\
\hline \hline
\end{tabular}


Table 3.c

\begin{tabular}{||l|l|l|l|l||}
\hline \hline & NAG95 & AG95 & NE95 & Total \\
\hline Total & 3683 & 4372 & 2186 & 10241 \\
Male & 2618 & 2019 & 943 & 5580 \\
Female & 1065 & 2353 & 1243 & 4661 \\
Mean Age & 35.07 & 41.80 & 35.81 & 38.11 \\
& & & & \\
Education & & & & \\
Primary & 253 & 1482 & 550 & 2285 \\
Gymnasium & 955 & 1935 & 944 & 3834 \\
Vocational & 1199 & 545 & 299 & 2043 \\
Foreman & 74 & 29 & 19 & 122 \\
Highschool & 938 & 360 & 344 & 1642 \\
HIPLUS & 99 & 14 & 14 & 127 \\
University & 165 & 7 & 16 & 188 \\
& & & & \\
Self-empl. & 127 & 2360 & & \\
Family help & 22 & 1822 & & \\
Regist. UE & 64 & 441 & 341 & \\
UE benfits & 37 & 366 & 305 & \\
Retired & 16 & 471 & 481 & \\
Homemaker & 3 & 347 & 555 & \\
Second job & 1178 & 156 & & \\
Search & 57 & 438 & & \\
& & & & \\
\hline \hline
\end{tabular}


Table 4.a. Moments of the posterior distribution. Non-agricultural sector, 1993

\begin{tabular}{||l|l|l|l|l||}
\hline \hline \multirow{3}{*}{ Variable } & \multicolumn{4}{|c||}{1993} \\
\cline { 2 - 5 } Const. & mean & PSTD & NSE & $\mathrm{R}$ \\
\cline { 2 - 5 } Gender & -6.091 & 0.1577 & 0.0020 & 1.0008 \\
Age & 0.732 & 0.0332 & 0.0001 & 1.0004 \\
Age`2 & 0.257 & 0.0083 & 0.0001 & 1.0011 \\
Gymnasium & -0.318 & 0.0109 & 0.0002 & 1.0011 \\
Vocational & 1.361 & 0.0473 & 0.0006 & 1.0006 \\
Foreman & 1.326 & 0.0552 & 0.0003 & 1.0000 \\
High school & 1.396 & 0.0589 & 0.0016 & 1.0006 \\
HIPLUS & 2.093 & 0.1598 & 0.0004 & 1.0001 \\
University & 2.193 & 0.1463 & 0.0035 & 1.0026 \\
\hline \hline
\end{tabular}

Table 4.b. Moments of the posterior distribution. Non-agricultural sector, 1994.

\begin{tabular}{||l|l|l|l|l||}
\hline \hline \multirow{3}{*}{ Variable } & \multicolumn{4}{|c||}{1994} \\
\cline { 2 - 5 } Const. & mean & PSTD & NSE & $\mathrm{R}$ \\
\cline { 2 - 5 } Gender & -4.710 & 0.1502 & 0.0025 & 1.0013 \\
Age & 0.834 & 0.0334 & 0.0003 & 1.0005 \\
Age`2 & 0.191 & 0.0082 & 0.0001 & 1.0005 \\
Gymnasium & -0.252 & 0.0108 & 0.0001 & 1.0003 \\
Vocational & 0.411 & 0.0490 & 0.0007 & 1.0011 \\
Foreman & 1.109 & 0.0554 & 0.0007 & 1.0008 \\
High school & 1.344 & 0.1427 & 0.0024 & 1.0013 \\
HIPLUS & 2.286 & 0.0594 & 0.0010 & 1.0016 \\
University & 2.286 & 0.1521 & 0.0032 & 1.0018 \\
Unyyyy & 0.0016 & 1.0005 \\
\hline \hline
\end{tabular}


Table 4.c. Moments of the posterior distribution. Non-agricultural sector, 1995

\begin{tabular}{||l|l|l|l|l||}
\hline \hline \multirow{3}{*}{ Variable } & \multicolumn{4}{|c||}{1995} \\
\cline { 2 - 5 } Const. & mean & PSTD & NSE & $\mathrm{R}$ \\
\cline { 2 - 5 } Gender & -4.267 & 0.1451 & 0.0008 & 1.0001 \\
Age & 0.820 & 0.0330 & 0.0002 & 1.0001 \\
Age`2 & 0.182 & 0.0080 & $2.8 \mathrm{E}-05$ & 1.0003 \\
Gymnasium & -0.255 & 0.0108 & $4.5 \mathrm{E}-05$ & 1.0004 \\
Vocational & 0.354 & 0.0493 & 0.0005 & 1.0008 \\
Foreman & 0.995 & 0.0550 & 0.0009 & 1.0013 \\
High school & 1.068 & 0.1400 & 0.0017 & 1.0006 \\
HIPLUS & 1.210 & 0.0588 & 0.0011 & 1.0016 \\
University & 1.860 & 0.1467 & 0.0019 & 1.0008 \\
\hline \hline
\end{tabular}


Table 5.a. Moments of the posterior distribution. Agricultural sector, 1993 .

\begin{tabular}{||l|l|l|l|l||}
\hline \hline \multirow{3}{*}{ Variable } & \multicolumn{4}{|c||}{1993} \\
\cline { 2 - 5 } Const. & mean & PSTD & NSE & $\mathrm{R}$ \\
\cline { 2 - 5 } Gender & -0.026 & 0.1366 & 0.0012 & 1.0004 \\
Age & -0.278 & 0.0314 & 0.0003 & 1.0003 \\
Age 2 & -0.013 & 0.0075 & 0.0001 & 1.0003 \\
Gymnasium & 0.038 & -0.0099 & 0.0001 & 1.0002 \\
Vocational & -0.939 & 0.0396 & 0.0004 & 1.0005 \\
Foreman & -1.407 & 0.1794 & 0.0005 & 1.0004 \\
High school & -1.049 & 0.0575 & 0.0074 & 1.0089 \\
HIPLUS & -1.834 & 0.2389 & 0.0003 & 1.0003 \\
University & -2.011 & 0.2426 & 0.0038 & 1.00019 \\
\hline \hline
\end{tabular}

Table 5.b. Moments of the posterior distribution. Agricultural sector, 1994 .

\begin{tabular}{|c|c|c|c|c|}
\hline \multirow[t]{2}{*}{ Variable } & \multicolumn{4}{|c|}{1994} \\
\hline & mean & PSTD & NSE & $\mathrm{R}$ \\
\hline Const. & 0.461 & 0.1286 & 0.0012 & 1.0004 \\
\hline Gender & -0.317 & 0.0304 & 0.0002 & 1.0001 \\
\hline Age & -0.028 & 0.0071 & 0.0001 & 1.0011 \\
\hline Age $^{\wedge} 2$ & 0.054 & 0.0094 & 0.0002 & 1.0014 \\
\hline Gymnasium & -0.257 & 0.0396 & 0.0004 & 1.0006 \\
\hline Vocational & -0.764 & 0.0496 & 0.0007 & 1.0013 \\
\hline Foreman & -1.237 & 0.1549 & 0.0039 & 1.0033 \\
\hline High school & -0.975 & 0.0541 & 0.0008 & 1.0012 \\
\hline HIPLUS & -1.711 & 0.1992 & 0.0032 & 1.0016 \\
\hline University & -1.942 & 0.2008 & 0.0045 & 1.0038 \\
\hline
\end{tabular}


Table 5.c. Moments of the posterior distribution. Agricultural sector, 1995 .

\begin{tabular}{|c|c|c|c|c|}
\hline \multirow{2}{*}{ Variable } & \multicolumn{4}{|c|}{1995} \\
\hline & mean & PSTD & NSE & $\mathrm{R}$ \\
\hline Const. & 0.812 & 0.1234 & 0.0012 & 1.0004 \\
\hline Gender & -0.379 & 0.0297 & 0.0002 & 1.0002 \\
\hline Age & -0.045 & 0.0069 & 0.0001 & 1.0002 \\
\hline $\mathrm{Age}^{\wedge} 2$ & 0.078 & 0.0091 & 0.0001 & 1.0004 \\
\hline Gymnasium & -0.177 & 0.0391 & 0.0003 & 1.0001 \\
\hline Vocational & -0.660 & 0.0483 & 0.0002 & 1.0000 \\
\hline Foreman & -0.907 & 0.1346 & 0.0017 & 1.0007 \\
\hline High schoo & -0.873 & 0.0522 & 0.0005 & 1.0006 \\
\hline HIPI & -1.433 & 0.1651 & 0.0034 & 1.0021 \\
\hline University & -1.955 & 0.1927 & 0.0039 & 1.0030 \\
\hline
\end{tabular}


Table 6.a. Moments of the posterior distribution. Not employed, 1993.

\begin{tabular}{|c|c|c|c|c|}
\hline \multirow[t]{2}{*}{ Variable } & \multicolumn{4}{|c|}{$\overline{1993}$} \\
\hline & mean & PSTD & NSE & $\mathrm{R}$ \\
\hline Const. & 4.110 & 0.1369 & 0.0027 & 1.0020 \\
\hline Gender & -0.433 & 0.0313 & 0.0002 & 1.0004 \\
\hline Age & -0.223 & 0.0076 & 0.0002 & 1.0032 \\
\hline Age $^{\wedge} 2$ & 0.257 & 0.0101 & 0.0003 & 1.0034 \\
\hline Gymnasium & -0.166 & 0.0421 & 0.0003 & 1.0002 \\
\hline Vocational & -0.373 & 0.0519 & 0.0006 & 1.0005 \\
\hline Foreman & -0.039 & 0.1492 & 0.0018 & 1.0008 \\
\hline High school & -0.297 & 0.0542 & 0.0006 & 1.0006 \\
\hline HIPLUS & -0.709 & 0.1616 & 0.0010 & 1.0001 \\
\hline University & -0.795 & 0.1496 & 0.0017 & 1.0005 \\
\hline
\end{tabular}

Table 6.b. Moments of the posterior distribution. Not employed, 1994.

\begin{tabular}{||l|l|l|l|l||}
\hline \hline \multirow{3}{*}{ Variable } & \multicolumn{4}{|c||}{1994} \\
\cline { 2 - 5 } Const. & mean & PSTD & NSE & $\mathrm{R}$ \\
\cline { 2 - 5 } Gender & 2.688 & 0.1367 & 0.0032 & 1.0027 \\
Age & -0.459 & 0.0320 & 0.0004 & 1.0006 \\
Age`2 & -0.166 & 0.0077 & 0.0001 & 1.0016 \\
Gymnasium & 0.197 & -0.0102 & 0.0002 & 1.0014 \\
Vocational & -0.215 & 0.0425 & 0.0007 & 1.0012 \\
Foreman & -0.065 & 0.1485 & 0.0014 & 1.0032 \\
High school & -0.234 & 0.0550 & 0.0019 & 1.0010 \\
HIPLUS & -0.847 & 0.1876 & 0.0025 & 1.0019 \\
University & -0.724 & 0.1588 & 0.0044 & 1.0038 \\
\hline \hline
\end{tabular}


Table 6.c. Moments of the posterior distribution. Not employed, 1995 .

\begin{tabular}{|c|c|c|c|c|}
\hline \multirow[t]{2}{*}{ Variable } & \multicolumn{4}{|c|}{$\overline{1995}$} \\
\hline & mean & PSTD & NSE & $\mathrm{R}$ \\
\hline Const. & 1.929 & 0.1314 & 0.0011 & 1.0005 \\
\hline Gender & -0.383 & 0.0319 & 0.0002 & 1.0002 \\
\hline Age & -0.140 & 0.0074 & 0.0001 & 1.0009 \\
\hline Age^2 & 0.171 & 0.0099 & 0.0001 & 1.0011 \\
\hline Gymnasium & -0.039 & 0.0426 & 0.0003 & 1.0001 \\
\hline Vocational & -0.210 & 0.0531 & 0.0007 & 1.0009 \\
\hline Foreman & $-1.7 \mathrm{E}-04$ & 0.1503 & 0.0034 & 1.0025 \\
\hline High school & -0.176 & 0.0552 & 0.0003 & 1.0001 \\
\hline HIPLUS & -0.480 & 0.1663 & 0.0032 & 1.0022 \\
\hline University & -0.458 & 0.1438 & 0.0025 & 1.0019 \\
\hline
\end{tabular}


Table 7.a. The posterior means for correlation coefficients.

\begin{tabular}{|c|c|c|c|c|c|c|c|c|c|c|}
\hline & & 2 NAG93 & NAG94 & 2 NAG95 & $\begin{array}{l}\text { AG93 } \\
\end{array}$ & AG94 & AG95 & $\begin{array}{l}\text { NE93 } \\
\end{array}$ & $\begin{array}{l}\text { NE94 } \\
\end{array}$ & 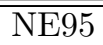 \\
\hline NAG93 & mean & 1 & 0.537 & 0.480 & -0.323 & -0.355 & $\begin{array}{l}-0.359 \\
\end{array}$ & -0.256 & -0.165 & -0.093 \\
\hline NAG94 & mean & & 1 & 0.505 & -0.316 & -0.372 & $\begin{array}{l}-0.368 \\
\end{array}$ & -0.231 & -0.195 & -0.110 \\
\hline NAG95 & mean & & & 1 & -0.276 & -0.320 & -0.399 & -0.215 & -0.174 & -0.131 \\
\hline AG93 & mean & & & & 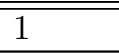 & 0.570 & $\overline{c 0.459}$ & "-0.286 & "-0.314 & 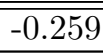 \\
\hline AG94 & mean & & & & & 1 & 0.501 & -0.222 & -0.320 & -0.261 \\
\hline AG95 & mean & & & & & & 1 & -0.101 & -0.176 & -0.299 \\
\hline$\overline{\text { NE93 }}$ & mean & & & & & & & 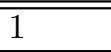 & 0.499 & 0.370 \\
\hline NE94 & mean & & & & & & & & 1 & 0.415 \\
\hline NE95 & mean & & & & & & & & & 1 \\
\hline
\end{tabular}


Table 7.b. Moments of the posterior distribution. Correlation coefficients .

\begin{tabular}{||l|l|l|l|l||}
\hline \hline \multirow{2}{*}{ Variable } & \multicolumn{4}{|c||}{1995} \\
\cline { 2 - 5 } NAG93-NAG94 & mean & PSTD & NSE & $\mathrm{R}$ \\
\cline { 2 - 5 } NAG93-NAG95 & 0.537 & 0.0089 & 0.0002 & 1.0019 \\
NAG93-AG93 & -0.323 & 0.0100 & 0.0002 & 1.0017 \\
NAG93-AG94 & -0.355 & 0.0133 & 0.0002 & 1.0018 \\
NAG93-AG95 & -0.359 & 0.0120 & 0.0002 & 1.0016 \\
NAG93-NE93 & -0.256 & 0.0135 & 0.0002 & 1.0012 \\
NAG93-NE94 & -0.165 & 0.0145 & 0.0006 & 1.0054 \\
NAG93-NE95 & -0.094 & 0.0147 & 0.0004 & 1.0074 \\
NAG94-NAG95 & 0.505 & 0.0095 & 0.0002 & 1.0026 \\
NAG94-AG93 & -0.316 & 0.0138 & 0.0003 & 1.0030 \\
NAG94-AG94 & -0.372 & 0.0124 & 0.0002 & 1.0018 \\
NAG94-AG95 & -0.368 & 0.0121 & 0.0002 & 1.0016 \\
NAG94-NE93 & -0.231 & 0.0139 & 0.0004 & 1.0045 \\
NAG94-NE94 & -0.195 & 0.0143 & 0.0006 & 1.0102 \\
NAG94-NE95 & -0.110 & 0.0146 & 0.0005 & 1.0058 \\
NAG95-AG93 & -0.276 & 0.0141 & 0.0002 & 1.0017 \\
NAG95-AG94 & -0.320 & 0.0131 & $4.7 \mathrm{E}-05$ & 1.0003 \\
NAG95-AG95 & -0.400 & 0.0119 & 0.0001 & 1.0006 \\
NAG95-NE93 & -0.215 & 0.0142 & 0.0005 & 1.0066 \\
NAG95-NE94 & -0.174 & 0.0144 & 0.0006 & 1.0077 \\
NAG95-NE95 & -0.131 & 0.0145 & 0.0005 & 1.0063 \\
\hline \hline
\end{tabular}


Table 7.b. (continued) Moments of the posterior distribution. Correlation

\begin{tabular}{||l|l|l|l|l||}
\multicolumn{5}{c||}{ coefficients . } \\
\hline \hline Variable & \multicolumn{4}{|c|}{1995} \\
\cline { 2 - 5 } AG93-AG94 & 0.570 & 0.0086 & 0.0001 & 1.0012 \\
AG93-AG95 & 0.459 & 0.0105 & 0.0002 & 1.0025 \\
AG93-NE93 & -0.286 & 0.0131 & 0.0004 & 1.0042 \\
AG93-NE94 & -0.314 & 0.0133 & 0.0004 & 1.0056 \\
AG93-NE95 & -0.259 & 0.0138 & 0.0003 & 1.0034 \\
AG94-AG95 & 0.501 & 0.0096 & 0.0002 & 1.0016 \\
AG94-NE93 & -0.222 & 0.0133 & 0.0003 & 1.0030 \\
AG94-NE94 & -0.320 & 0.0128 & 0.0004 & 1.0064 \\
AG94-NE95 & -0.261 & 0.0135 & 0.0004 & 1.0039 \\
AG95-NE93 & -0.101 & 0.0136 & 0.0004 & 1.0052 \\
AG95-NE94 & -0.176 & 0.0137 & 0.0005 & 1.0074 \\
AG95-NE95 & -0.299 & 0.0129 & 0.0004 & 1.0052 \\
NE93-NE94 & 0.499 & 0.0093 & 0.0001 & 1.0001 \\
NE94-NE95 & 0.370 & 0.0114 & 0.0001 & 1.0006 \\
NE94-NE95 & -0.415 & 0.0107 & 0.0001 & 1.0010 \\
\hline \hline
\end{tabular}


Figure 1: Employment probability. Non-agricultural sector.
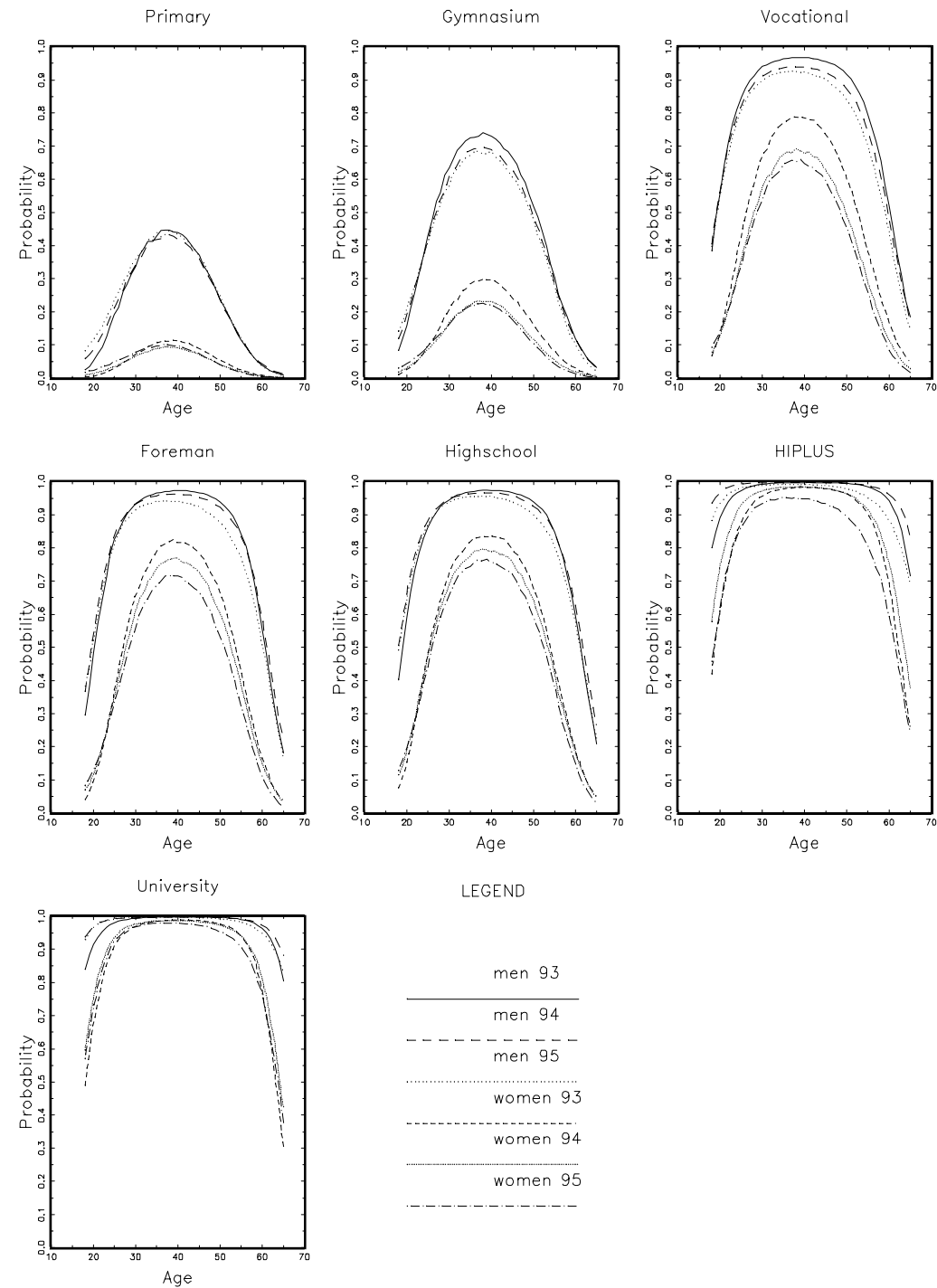

LEGEND

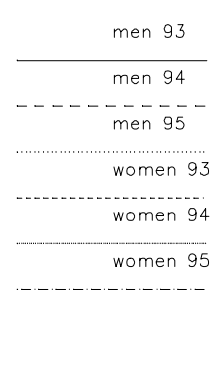


Figure 2: Employment probability. Agricultural sector.
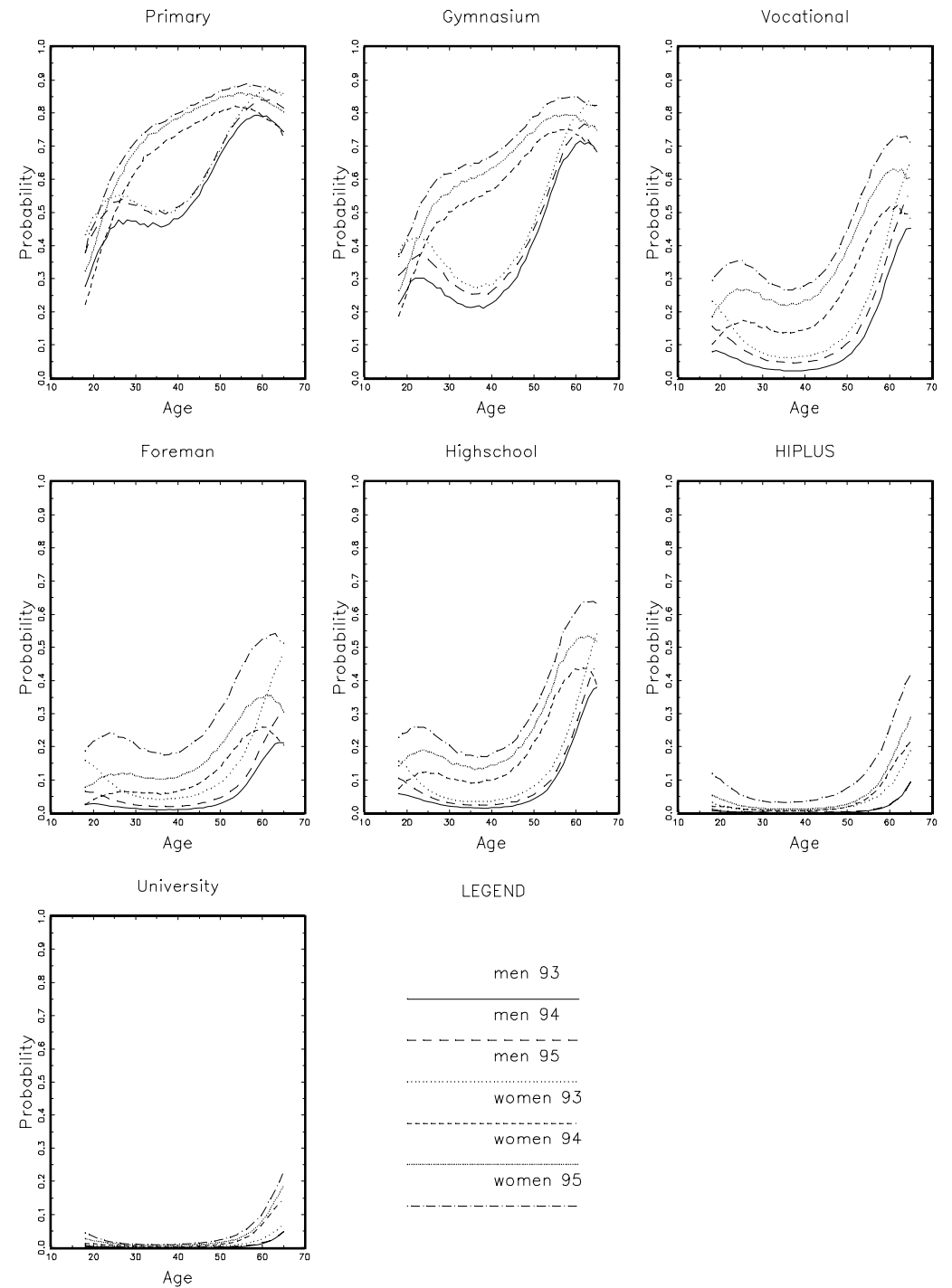

LEGEND

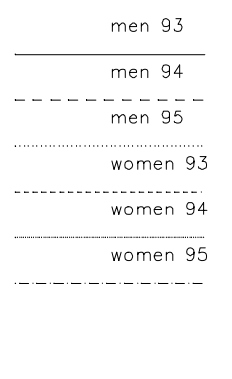


Figure 3: Probability of not working.
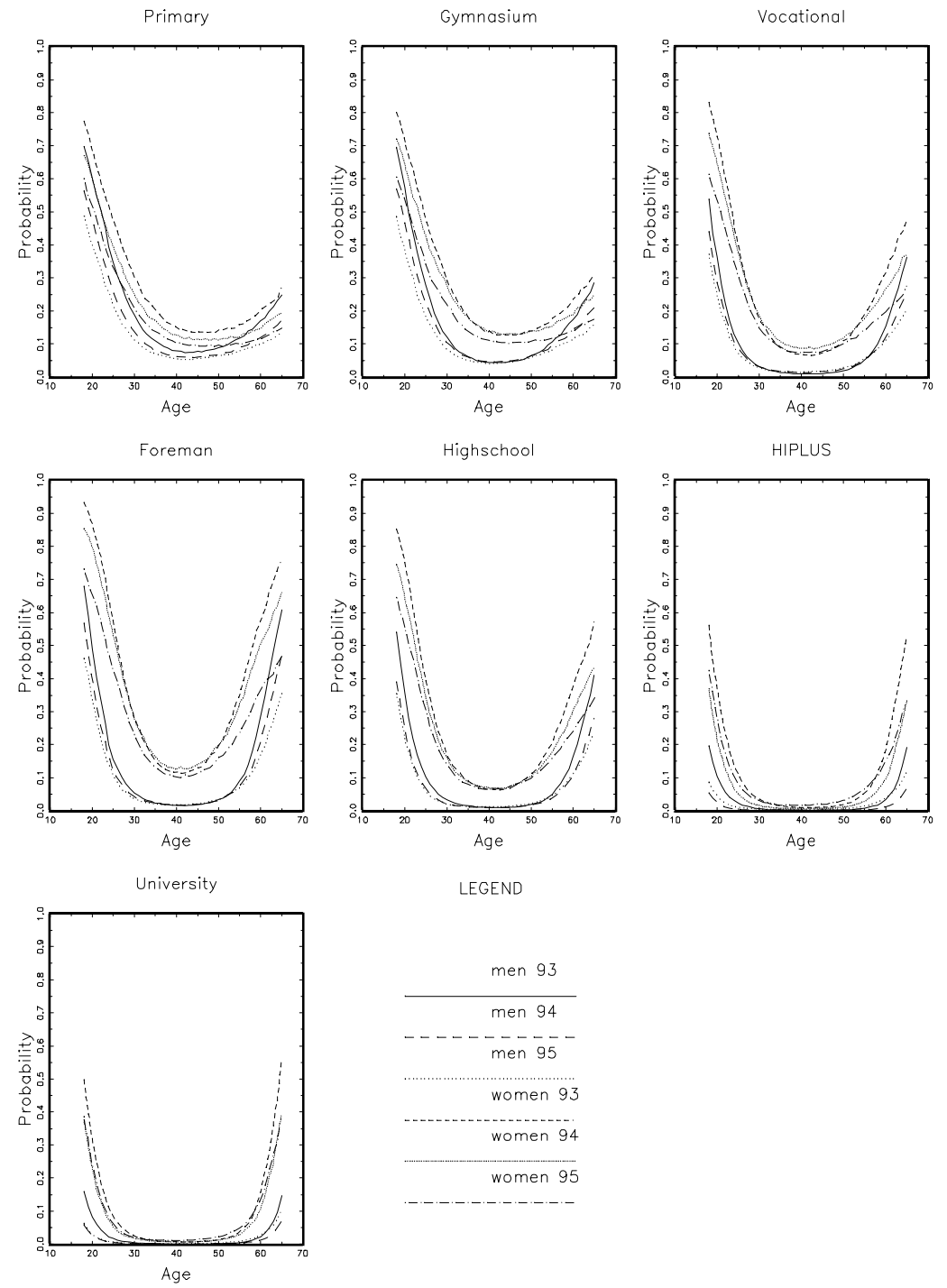

LEGEND

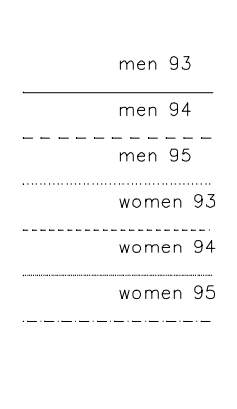


Figure 4: Transition probability. NAG to AG
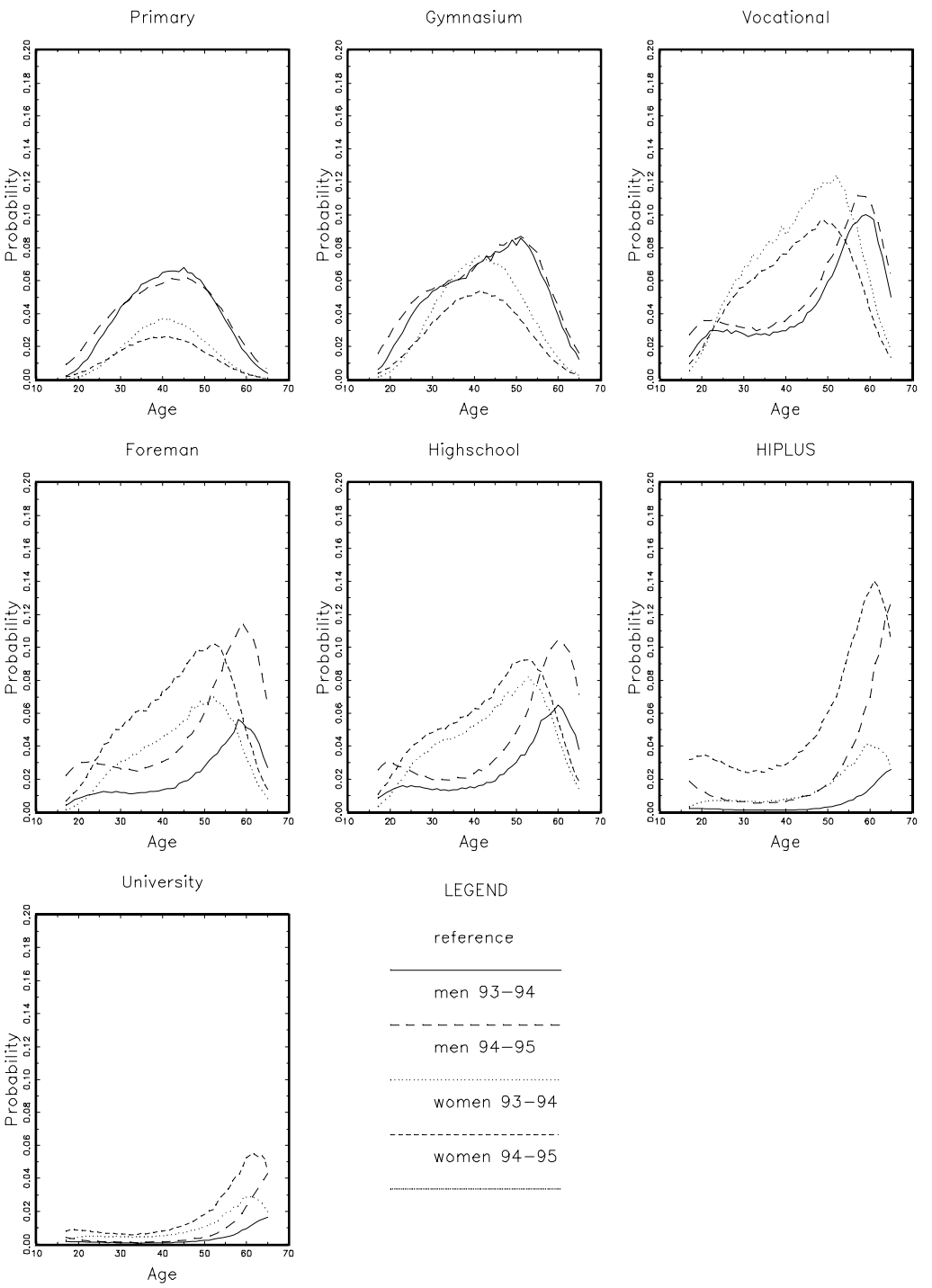
Figure 5: Conditional probability. NAG to AG.
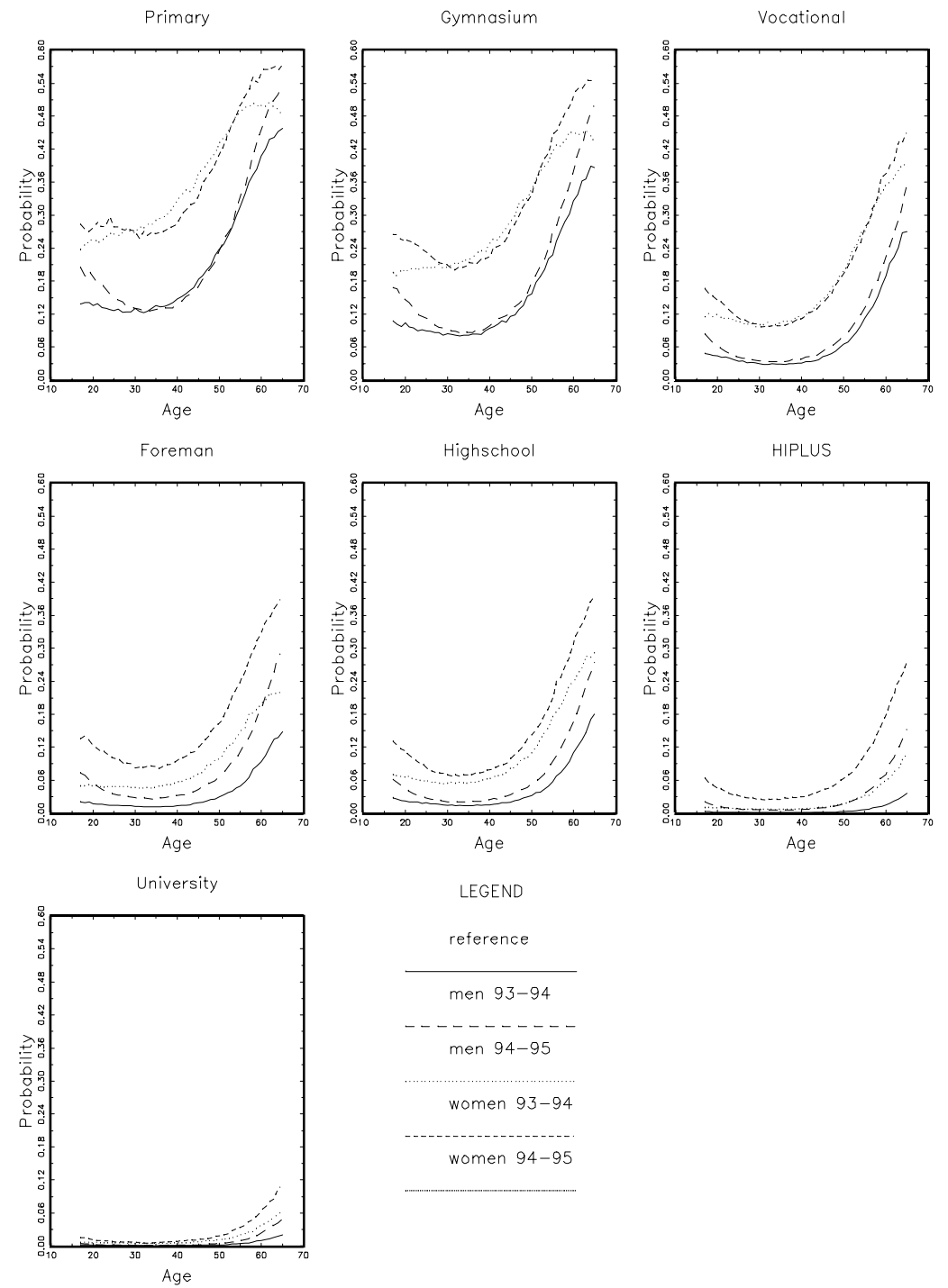
Figure 6: Transition probability. NAG to NE
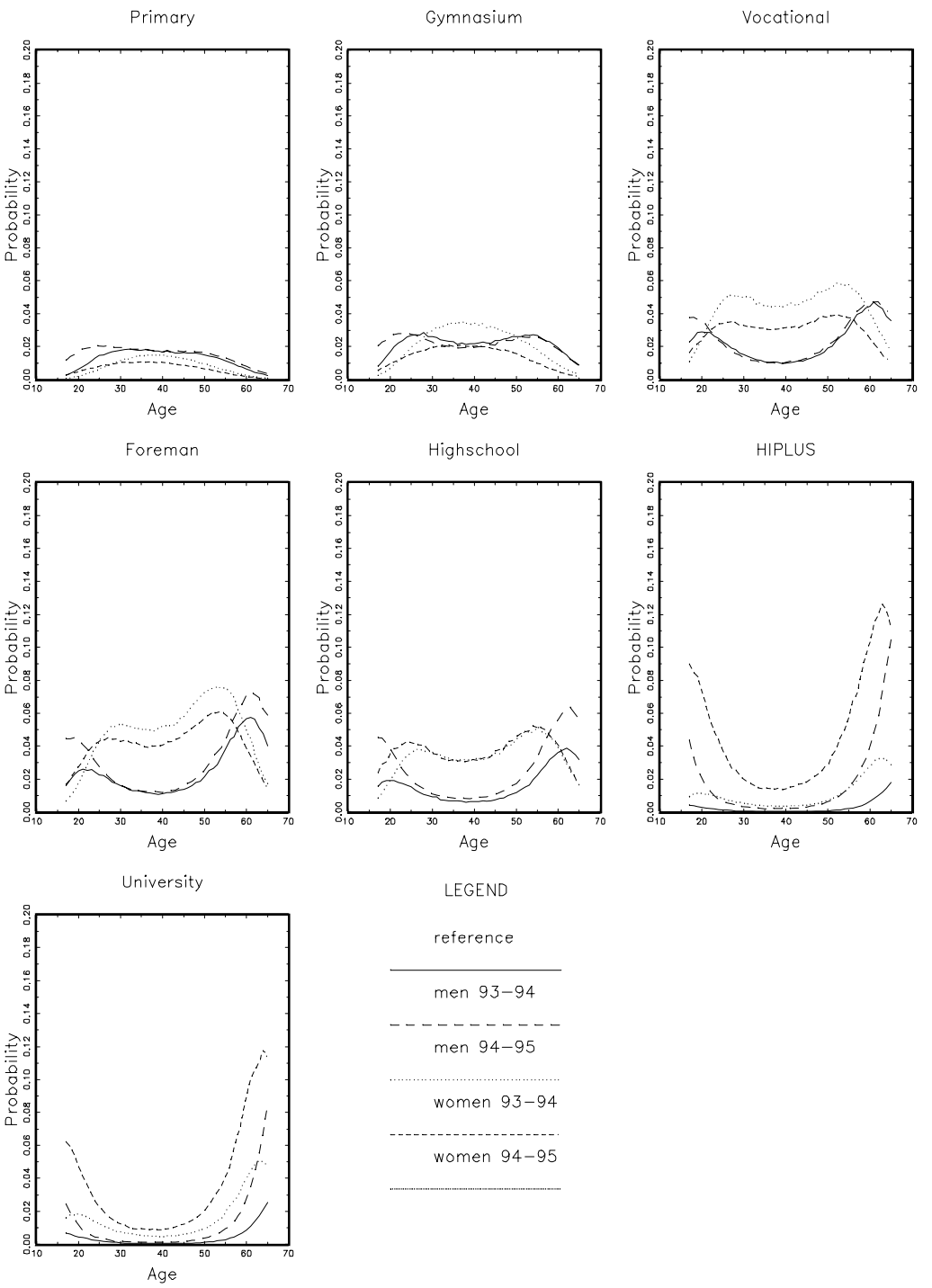
Figure 7: Conditional probability. NAG to NE.
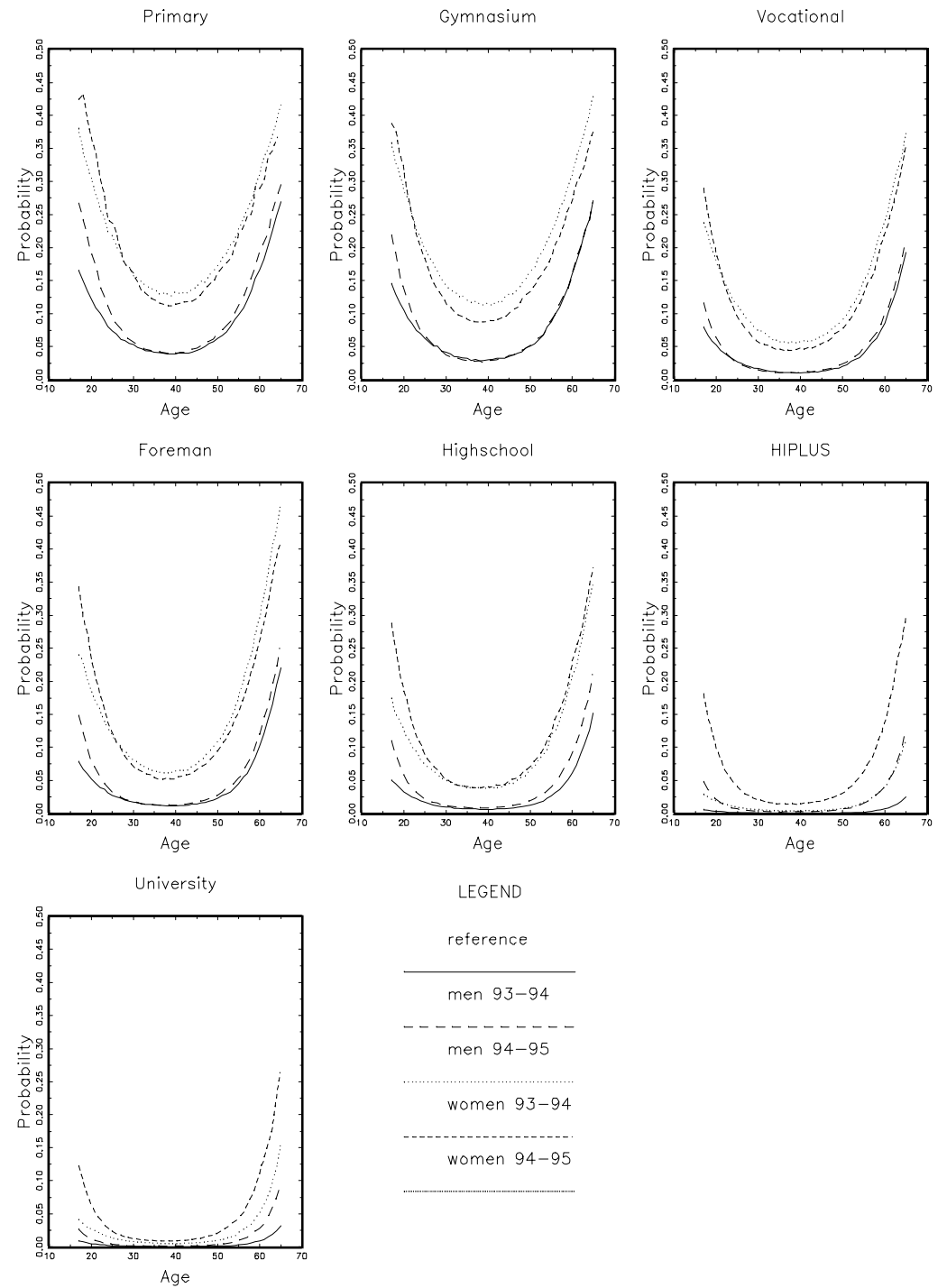
Figure 8: Transition probability. NE to AG
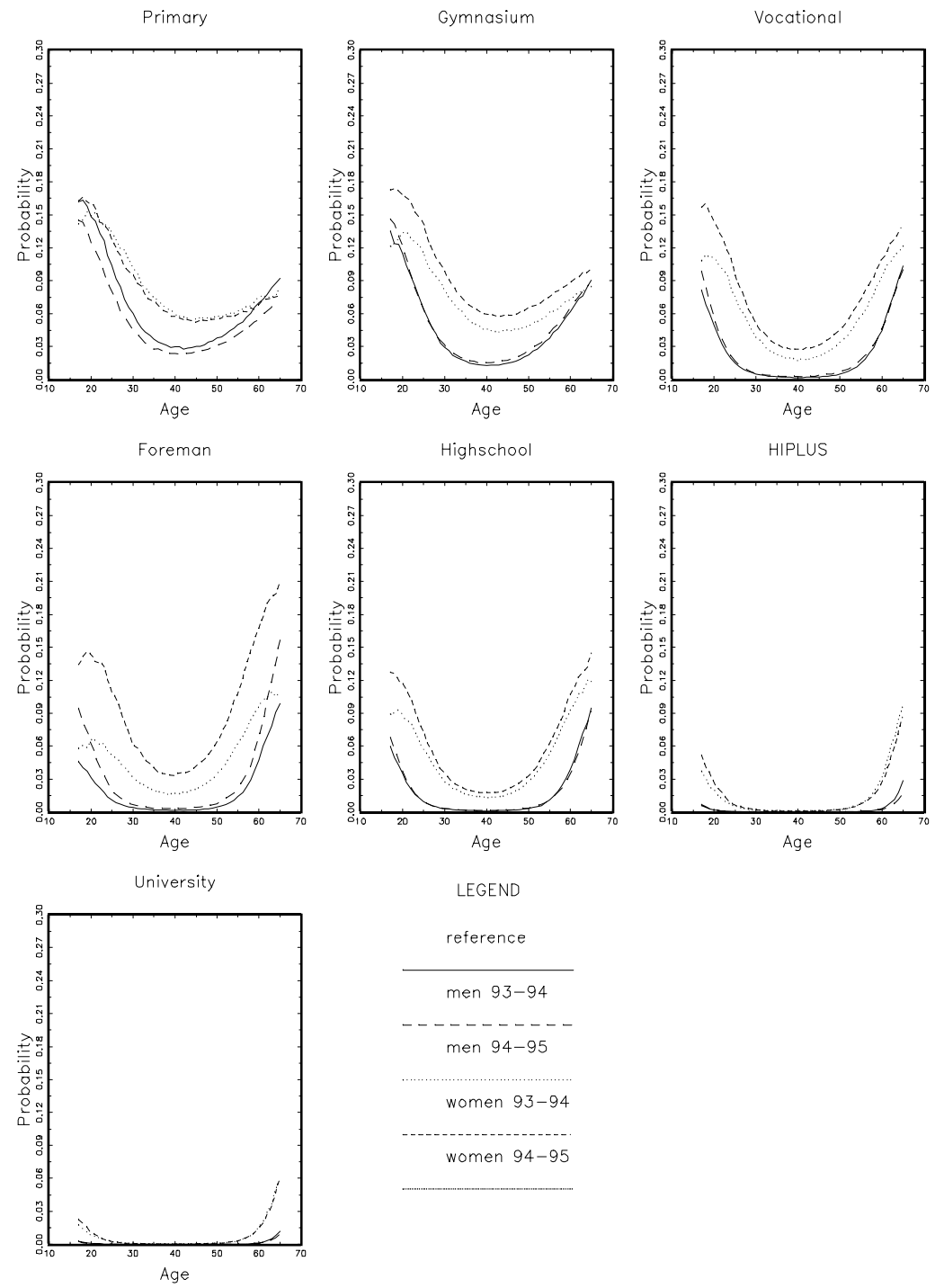
Figure 9: Conditional probability. NE to AG
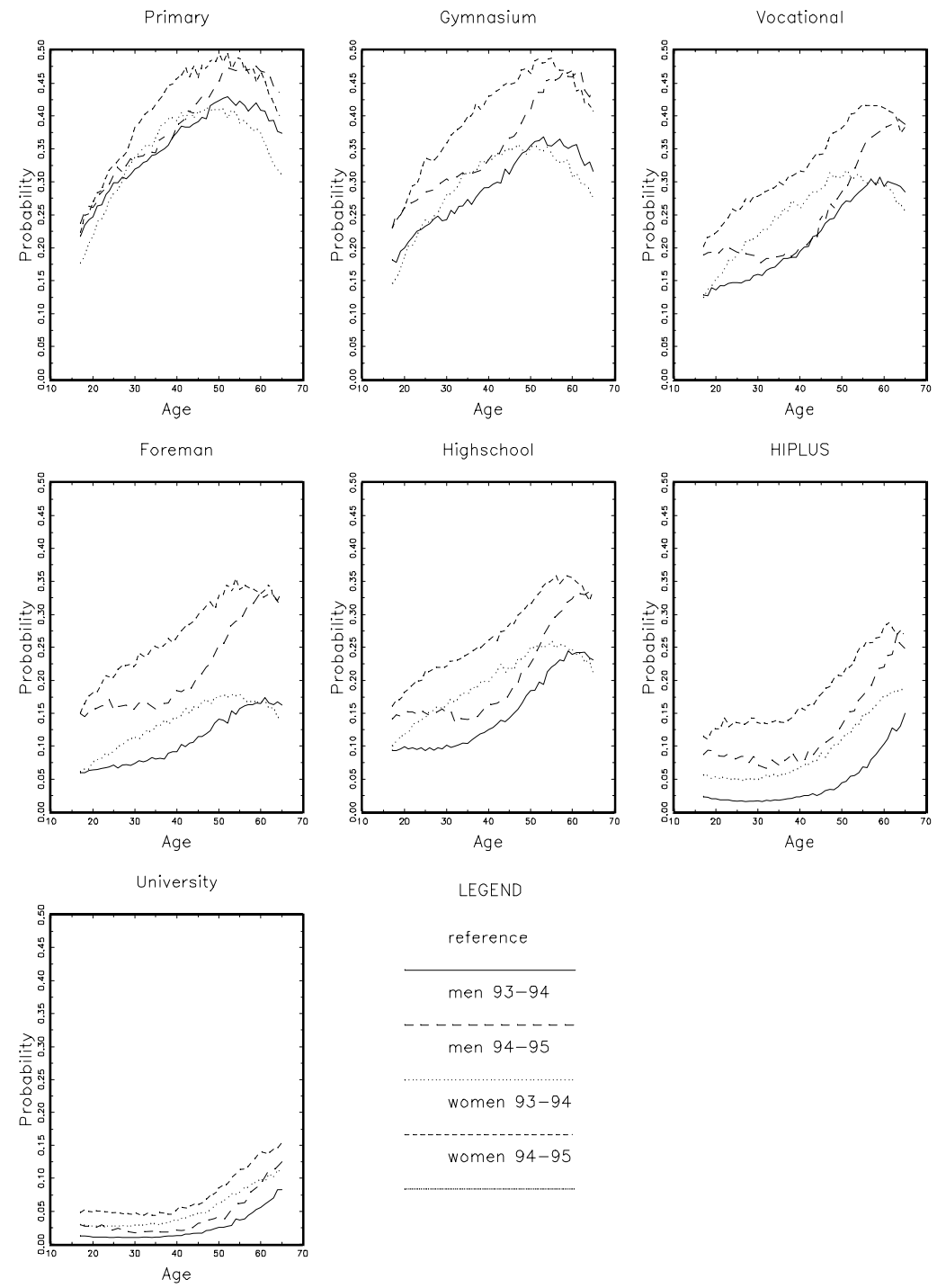
Figure 10: Transition probability. Net flows NAG to AG
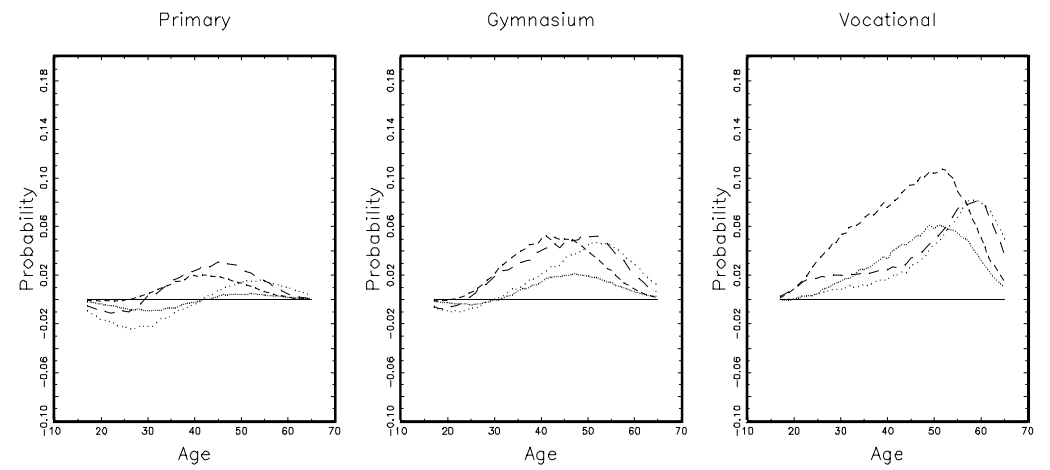

Foreman

Highschool
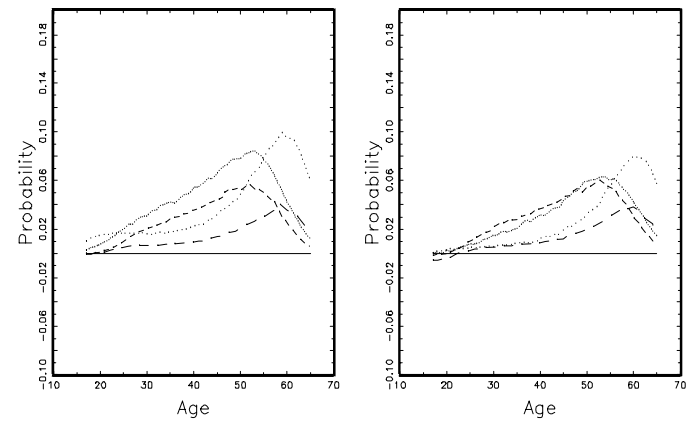

HIPLUS

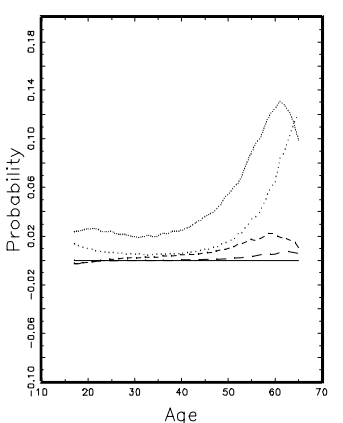

University

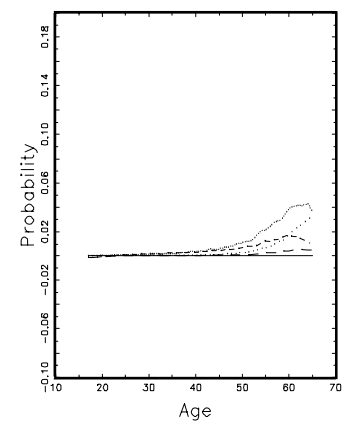

LEGEND

reference

men 93-94

men $94-95$

women 93-94

women 94-95 
Figure 11: Conditional probability. Net flows NAG to AG.
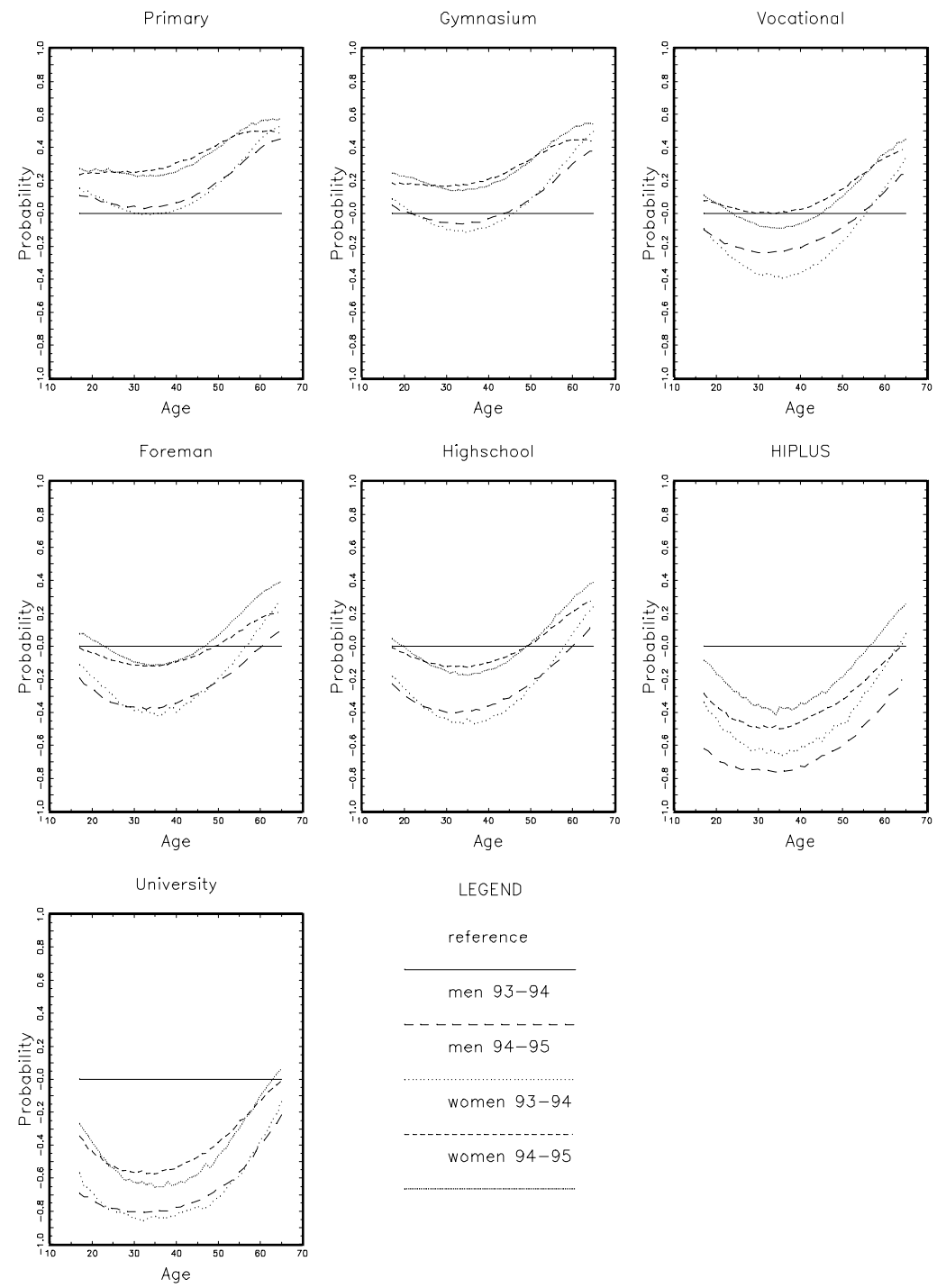


\section{IZA Discussion Papers}

\begin{tabular}{|c|c|c|c|c|}
\hline No. & Author(s) & Title & Area & Date \\
\hline 659 & $\begin{array}{l}\text { D. Byrne } \\
\text { E. Strobl }\end{array}$ & $\begin{array}{l}\text { Defining Unemployment in Developing } \\
\text { Countries: Evidence from Trinidad and Tobago }\end{array}$ & 4 & $12 / 02$ \\
\hline 660 & $\begin{array}{l}\text { E. Strobl } \\
\text { R. Thornton }\end{array}$ & $\begin{array}{l}\text { Do Large Employers Pay More in Developing } \\
\text { Countries? The Case of Five African Countries }\end{array}$ & 4 & $12 / 02$ \\
\hline 661 & $\begin{array}{l}\text { E. Strobl } \\
\text { F. Walsh }\end{array}$ & $\begin{array}{l}\text { Efficiency Wages and Effort: Are Hard Jobs } \\
\text { Better? }\end{array}$ & 3 & $12 / 02$ \\
\hline 662 & $\begin{array}{l}\text { E. Strobl } \\
\text { F. Walsh }\end{array}$ & $\begin{array}{l}\text { Getting It Right: Employment Subsidy or } \\
\text { Minimum Wage? }\end{array}$ & 3 & $12 / 02$ \\
\hline 663 & $\begin{array}{l}\text { A. B. Krueger } \\
\text { P. Zhu }\end{array}$ & $\begin{array}{l}\text { Another Look at the New York City School } \\
\text { Voucher Experiment }\end{array}$ & 6 & $12 / 02$ \\
\hline 664 & $\begin{array}{l}\text { J. R. Skaksen } \\
\text { A. Sørensen }\end{array}$ & $\begin{array}{l}\text { Skill Upgrading and Rigid Relative Wages: The } \\
\text { Case of Danish Manufacturing }\end{array}$ & 2 & $12 / 02$ \\
\hline 665 & H. Görg & $\begin{array}{l}\text { Fancy a Stay at the "Hotel California"? Foreign } \\
\text { Direct Investment, Taxation and Firing Costs }\end{array}$ & 2 & $12 / 02$ \\
\hline 666 & $\begin{array}{l}\text { P. Arnds } \\
\text { H. Bonin }\end{array}$ & $\begin{array}{l}\text { Frühverrentung in Deutschland: Ökonomische } \\
\text { Anreize und institutionelle Strukturen }\end{array}$ & 7 & $12 / 02$ \\
\hline 667 & $\begin{array}{l}\text { P. Arnds } \\
\text { H. Bonin }\end{array}$ & $\begin{array}{l}\text { Arbeitsmarkteffekte und finanzpolitische Folgen } \\
\text { der demographischen Alterung in Deutschland }\end{array}$ & 7 & $12 / 02$ \\
\hline 668 & $\begin{array}{l}\text { J. Meckl } \\
\text { S. Zink }\end{array}$ & $\begin{array}{l}\text { Solow and Heterogeneous Labor: A } \\
\text { Neoclassical Explanation of Wage Inequality }\end{array}$ & 3 & $12 / 02$ \\
\hline 669 & $\begin{array}{l}\text { A. C. D'Addio } \\
\text { I. De Greef } \\
\text { M. Rosholm }\end{array}$ & $\begin{array}{l}\text { Assessing Unemployment Traps in Belgium } \\
\text { Using Panel Data Sample Selection Models }\end{array}$ & 2 & $12 / 02$ \\
\hline 670 & $\begin{array}{l}\text { M. Botticini } \\
\text { Z. Eckstein }\end{array}$ & $\begin{array}{l}\text { From Farmers to Merchants: A Human Capital } \\
\text { Interpretation of Jewish Economic History }\end{array}$ & 5 & $12 / 02$ \\
\hline 671 & $\begin{array}{l}\text { A. Constant } \\
\text { S. Konstantopoulos }\end{array}$ & $\begin{array}{l}\text { School Effects and Labor Market Outcomes for } \\
\text { Young Adults in the 1980s and 1990s }\end{array}$ & 1 & $12 / 02$ \\
\hline 672 & $\begin{array}{l}\text { A. Constant } \\
\text { D. Massey }\end{array}$ & $\begin{array}{l}\text { Self-Selection, Earnings, and Out-Migration: } \\
\text { A Longitudinal Study of Immigrants to Germany }\end{array}$ & 1 & $12 / 02$ \\
\hline 673 & $\begin{array}{l}\text { A. L. Booth } \\
\text { M. Francesconi } \\
\text { J. Frank }\end{array}$ & $\begin{array}{l}\text { Labour as a Buffer: Do Temporary Workers } \\
\text { Suffer? }\end{array}$ & 2 & $12 / 02$ \\
\hline 674 & $\begin{array}{l}\text { D. A. Cobb-Clark } \\
\text { V. Hildebrand }\end{array}$ & $\begin{array}{l}\text { The Wealth and Asset Holdings of U.S.-Born } \\
\text { and Foreign-Born Households: Evidence from } \\
\text { SIPP Data }\end{array}$ & 6 & $12 / 02$ \\
\hline 675 & $\begin{array}{l}\text { J. Konings } \\
\text { O. Kupets } \\
\text { H. Lehmann }\end{array}$ & $\begin{array}{l}\text { Gross Job Flows in Ukraine: Size, Ownership } \\
\text { and Trade Effects }\end{array}$ & 4 & $12 / 02$ \\
\hline 676 & A. Voicu & $\begin{array}{l}\text { Agriculture: Transition Buffer or Black Hole? } \\
\text { A Three-State Model of Employment Dynamics }\end{array}$ & 4 & $12 / 02$ \\
\hline
\end{tabular}

An updated list of IZA Discussion Papers is available on the center's homepage www.iza.org. 